\title{
Oligodendrocyte Progenitor Cell Proliferation and Lineage Progression Are Regulated by Glutamate Receptor-Mediated $\mathrm{K}^{+}$ Channel Block
}

\author{
Vittorio Gallo, ${ }^{1}$ Jia Min Zhou, ${ }^{1}$ Chris J. McBain, ${ }^{1}$ Paul Wright,, ${ }^{1}$ Peter L. Knutson, ${ }^{1}$ and Regina C. Armstrong ${ }^{2}$ \\ 'Laboratory of Cellular and Molecular Neurophysiology, National Institute of Child Health and Human Development, \\ National Institutes of Health, Bethesda, Maryland 20892, and 2Department of Anatomy and Cell Biology, Uniformed \\ Service University of the Health Sciences, Bethesda, Maryland 20814
}

We have analyzed the role of glutamate and its receptors (GluRs) in regulating the development of oligodendrocytes. Activation of AMPA-preferring GluRs with selective agonists inhibited proliferation of purified cortical oligodendrocyte progenitor $(\mathrm{O}-2 \mathrm{~A})$ cells cultured with different mitogens, as measured by $\left[{ }^{3} \mathrm{H}\right]$ thymidine incorporation or bromodeoxyuridine staining. In contrast, activation of GABA or muscarinic receptors did not affect O-2A proliferation. Cell viability and apoptosis assays demonstrated that the inhibition of O-2A proliferation was not attributable to a cytotoxic action of GluR agonists, and was reversible. Activation of GluRs prevented lineage progression from the $\mathrm{O}-2 \mathrm{~A}\left(\mathrm{GD}^{+} /\right.$nestin $\left.^{+}\right)$stage to the prooligodendroblast $\left(\mathrm{O}^{+}\right)$stage, but did not affect $\mathrm{O}-2 \mathrm{~A}$ migration. Additional experiments examined the membrane ionic channels mediating these GluR activation effects. We found that proliferating $\mathrm{O}-2 \mathrm{~A}$ cells expressed functional delayed rectifier $\mathrm{K}^{+}$channels, which were absent in pro-oligodendroblasts. GluR agonists and the $\mathrm{K}^{+}$channel blocker tetraethylammonium (TEA) strongly inhibited delayed rectifier $\mathrm{K}^{+}$currents in $\mathrm{O}-2 \mathrm{~A}$ cells. TEA reproduced the effects of GluR activation on $\mathrm{O}-2 \mathrm{~A}$ proliferation and lineage progression in the same concentration range that blocked delayed rectifier $\mathrm{K}^{+}$currents. These results indicate that glutamate regulates oligodendrogenesis specifically at the $\mathrm{O}-2 \mathrm{~A}$ stage by modulating $\mathrm{K}^{+}$channel activity.

Key words: AMPA receptors; O-2A cells; glia; cell migration; tetraethylammonium; delayed rectifier $\mathrm{K}^{+}$channels
Classical neurotransmitters, including amino acids, can influence neural cell development in the mammalian CNS (Komuro and Rakic, 1993; Lauder, 1993; Behar et al., 1994; Thomas et al., 1995). The physiological action of the major excitatory neurotransmitter glutamate is mediated through different receptor subtypes that are expressed in both neurons and glia (Mayer and Westbrook, 1987; Gallo and Russell, 1995). In the developing and mature CNS, glutamate receptors (GluRs) in neurons are involved in synaptic transmission and plasticity, but their role in glial cells is unknown.

Oligodendrocytes are generated from progenitor $(\mathrm{O}-2 \mathrm{~A})$ cells that proliferate in CNS germinal zones and migrate to formative white matter regions, where they further proliferate, differentiate, and form myelin sheaths around axons (Reynolds and Wilkin, 1988; Levison and Goldman, 1993; Luskin and McDermott, 1994; Zerlin and Goldman, 1995). Distinct and sequential stages of

\footnotetext{
Received Dec. 8, 1995; revised Jan. 17, 1996; accepted Jan. 24, 1996.

This work was supported in part by Uniformed Service University of the Health Sciences (USUHS) Grant RO70CB to R.C.A. The opinions expressed are the private views of the authors and should not be construed as official or necessarily reflecting the views of USUHS or the Department of Defense. We thank Judy Harvey White for HPLC analysis of glutamate in the culture media; Li Jin Chew, Fei Huang, Gianmaria Maccaferri, Mark Mayer, Mario Pende, Steve Scherer, and Joan Schwartz for critical comments on an early version of this manuscript; and Monique DuboisDalcq and Joan Schwartz for helpful discussions.

Correspondence should be addressed to Dr. Vittorio Gallo, Laboratory of Cellular and Molecular Neurophysiology, National Institute of Child Health and Human Development, National Institutes of Health, Building 49, Room 5A78, Bethesda, MD 20892

Dr. Wright's present address: Biological Carcinogenesis and Development Program, National Cancer Institute, Frederick Cancer Research and Development Center, Frederick, MD 21702-1201

Copyright (C) 1996 Society for Neuroscience $0270-6474 / 96 / 162659-12 \$ 05.00 / 0$
}

oligodendrocyte maturation have been characterized, based on the expression of developmentally regulated antigens, which also identify proliferative versus nonproliferative stages of $\mathrm{O}-2 \mathrm{~A}$ development (Sommer and Schachner, 1981; Raff et al., 1983; Goldman et al., 1984; Levi et al., 1986; Gard and Pfeiffer, 1990; Warrington and Pfeiffer, 1992; Gallo and Armstrong, 1995). The expression pattern of these antigens is reproduced in vitro as well as in vivo (Reynolds and Wilkin, 1988; Warrington and Pfeiffer, 1992; Gallo and Armstrong, 1995). For example, the intermediate filament protein nestin is highly expressed in dividing pre-O-2A and $\mathrm{O}-2 \mathrm{~A}$ cells, but downregulated in postmitotic $\mathrm{O}^{+}$prooligodendroblasts and $\mathrm{O}^{+}$oligodendrocytes (Gallo and Armstrong, 1995). Distinct changes in the membrane channel phenotype of O-2A cells also occur during lineage progression (Sontheimer et al., 1989; Barres et al., 1990; von Blankenfeld et al., 1991), indicating that some of these membrane constituents may have a role in the regulation of $\mathrm{O}-2 \mathrm{~A}$ cell differentiation.

Oligodendrocyte development takes place during the late gestational and early postnatal periods, after neuronal maturation has occurred (Curtis et al., 1988; LeVine and Goldman, 1988; Skoff, 1990). O-2A cells proliferate, migrate, and differentiate in an environment in which cells that can produce glutamate, i.e., neurons and astrocytes, are already present (Jacobson, 1991). O-2A cells express functional GluRs in vivo and in vitro (Gallo et al., 1989; Barres et al., 1990; Wyllie et al., 1991; Fulton et al., 1992; Borges et al., 1994; Holzwarth et al., 1994; Patneau et al., 1994; Berger et al., 1995). By using a combined molecular and electrophysiological approach, we have demonstrated previously that cultured O-2A cells coexpress functional kainate- and AMPApreferring receptors (Patneau et al., 1994). 

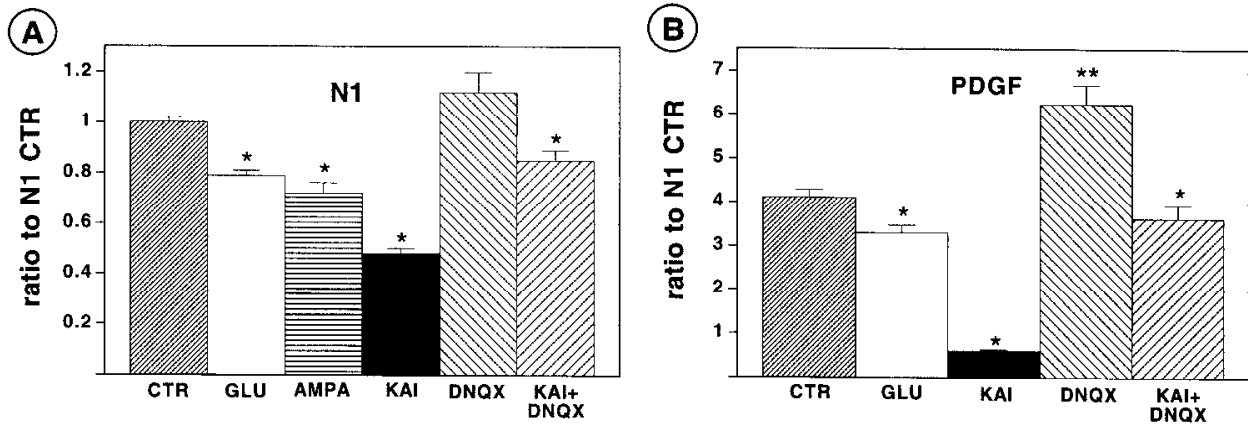

Figure 1. Glutamate receptor activation inhibits $\mathrm{O}-2 \mathrm{~A}$ cell proliferation: $\left[{ }^{3} \mathrm{H}\right]$ thymidine incorporation assays. O-2A progenitor cells were cultured in DME-N $1+0.5 \%$ FBS $(A)$, with PDGF (B), bFGF $(C)$, or PDGF + bFGF $(D)$. Cells were plated in 24-well plates. After $2 \mathrm{hr}, \mathrm{PDGF}$ and/or bFGF (both $10 \mathrm{ng} / \mathrm{ml}$ ) in combination with kainic acid $(K A I ; 200 \mu \mathrm{M})$, AMPA $(200 \mu \mathrm{M})$, glutamate $(G L U ; 200 \mu \mathrm{M})$, or DNQX (30 $\mu \mathrm{M})$ were added to the cultures as well as $\left[{ }^{3} \mathrm{H}\right]$ thymidine $(0.5 \mu \mathrm{Ci} / \mathrm{ml})$. After $22 \mathrm{hr}$, $\left[{ }^{3} \mathrm{H}\right]$ thymidine incorporation was measured by trichloroacetic acid precipitation and scintillation counting. Control cells $(C T R)$ in $\mathrm{N} 1$ incorporated $3508 \pm 371 \mathrm{cpm} / \mathrm{well} / 22 \mathrm{hr}$ (average $\pm \mathrm{SEM}, n=9 ; 30,000$ cells/well). Averages of three experiments in triplicate \pm SEM are shown. ${ }^{*} p<0.001 ; * * p<0.01$ *** $p<0.05$ compared with their respective controls (Student's $t$ test). Cells in kainate + DNQX were compared with cells in kainate alone for statistical analysis. Kainate and AMPA similarly inhibited proliferation of $\mathrm{O}-2 \mathrm{~A}$ cells cultured in B104-CM (data not shown).
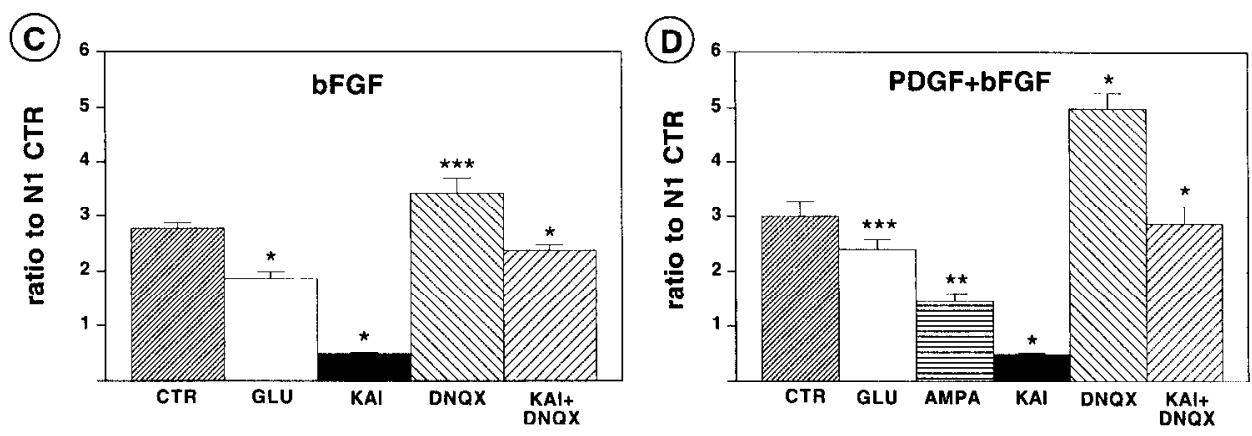

In the present study, we analyzed potential functions of GluRs in modulating proliferation, migration, and differentiation of $\mathrm{O}-2 \mathrm{~A}$ progenitor cells during development. We used in vitro bioassays and soluble factors, which stimulate mitosis, motility, and maturation of $\mathrm{O}-2 \mathrm{~A}$ cells, to reproduce the events that occur during CNS development. We report that activation of AMPA GluRs inhibits cortical O-2A cell division in a reversible manner and prevents differentiation to the pro-oligodendroblast stage by blocking delayed rectifier $\mathrm{K}^{+}$channels. These cationic channels are expressed only in proliferative O-2A cells and are drastically downregulated in postmitotic pro-oligodendroblasts (see also Sontheimer et al., 1989; Barres et al., 1990; Borges et al., 1994). Our analysis not only reveals a physiological role for GluR in glial development, but uncovers a mechanism that involves other membrane channels the function of which in $\mathrm{O}-2 \mathrm{~A}$ cells was previously unknown. Our findings indicate that neurotransmitters and their receptors can control glial proliferation and maturation and, therefore, may modulate the cellular development of the CNS.

\section{MATERIALS AND METHODS}

Cell cultures. Purified cortical O-2A progenitor cultures were prepared by modifications of previously described methods (Armstrong et al., 1990a; McKinnon et al., 1990). Briefly, embryonic day 20 (E20) Sprague-Dawley rats were killed following the National Institutes of Health Animal Welfare guidelines, and cortices were removed, mechanically dissociated, suspended in DMEM (Gibco, Gaithersburg, MD) containing 10\% fetal bovine serum (FBS; HyClone, Logan, UT), and plated in plastic T75 flasks. After $12 \mathrm{~d}$ in culture, O-2A progenitor cells growing on top of a confluent monolayer of astrocytes were detached by overnight shaking (McCarthy and de Vellis, 1980). Contaminating microglial cells were eliminated further by plating this fraction on plastic culture dishes for 1 hr. The O-2A progenitor cells, which do not attach well to plastic, were collected by gently washing the dishes, replated $\left(3 \times 10^{4} \mathrm{cells} / \mathrm{cm}^{2}\right.$, unless otherwise specified) onto poly-D-ornithine-coated plates $(0.1 \mathrm{mg} / \mathrm{ml})$, and cultured in DME-N1 biotin-containing medium. After $2 \mathrm{hr}$, plateletderived growth factor (PDGF; human $\mathrm{AB}$, heterodimer form, $10 \mathrm{ng} / \mathrm{ml}$ ), basic fibroblast growth factor (bFGF; human, $10 \mathrm{ng} / \mathrm{ml}$ ), PDGF + bFGF (both from Upstate Biotechnology, Lake Placid, NY), or $30 \%$ B104conditioned medium (B104-CM) was added to the culture medium. O-2A cells were cultured for 1-3 d and treated every $24 \mathrm{hr}$ with PDGF and/or bFGF, or B104-CM. Differentiation into $\mathrm{O}^{+}$, postmitotic prooligodendroblasts was promoted by withdrawing the mitogenic factors and growing the O-2A progenitors for an additional 2-3 d in DME-N1 medium containing $0.5 \%$ FBS.

Cultures enriched in different cell types were characterized immunocytochemically by using cell type-specific antibodies (see below). Cell cultures used for immunostaining were grown on glass coverslips precoated with poly-D-ornithine. In cortical cultures enriched in O-2A progenitors, $>95 \%$ of the cells were labeled by the LB1 (anti-GD3) antibody, after $24 \mathrm{hr}$ in vitro with PDGF, PDGF + bFGF, or B104-CM. In prooligodendroblast-enriched cultures, $>85 \%$ of the cells were $\mathrm{O}^{+}$, after 48 hr of culture in the absence of mitogens.

Cell proliferation assays. Purified cortical O-2A cells were plated in DME-N1 biotin-containing medium with $0.5 \%$ FBS in 24-multiwell plates $\left(\left[{ }^{3} \mathrm{H}\right]\right.$ thymidine incorporation assays), or on 25 -mm-diameter coverslips [bromodeoxyuridine (BrdU) incorporation assays] at a density of $2 \times 10^{4}$ cells $/ \mathrm{cm}^{2}$. After $2 \mathrm{hr}$, PDGF and/or bFGF, kainic acid (Sigma, St. Louis, MO), AMPA (Tocris Cookson, Bristol, UK), glutamate (Sigma), 6,7dinitroquinoxaline-2,3-dione (DNQX; Tocris Cookson), GABA, muscimol, or carbachol were added to the cultures along with [methyl$\left.{ }^{3} \mathrm{H}\right)$ thymidine $(0.5 \mu \mathrm{Ci} / \mathrm{ml}, 85 \mathrm{Ci} / \mathrm{mmol}$; Amersham, Arlington Heights, IL). Unless otherwise stated, after $22 \mathrm{hr}$ cells were lysed and $\left[{ }^{3} \mathrm{H}\right]$ thymidine incorporation was measured by precipitation with $10 \%$ trichloroacetic acid and scintillation counting.

For BrdU staining, cells were pulsed with $25 \mu \mathrm{M}$ BrdU for $20 \mathrm{hr}$, fixed in $4 \%$ paraformaldehyde for $10 \mathrm{~min}$ at room temperature, and incubated with $0.07 \mathrm{~N} \mathrm{NaOH}$ for $10 \mathrm{~min}$ at room temperaturc. After washing in PBS, cells were fixed in $4 \%$ paraformaldehyde for $10 \mathrm{~min}$ and permeabilized in $0.2 \%$ Triton X-100 in PBS for 10 min. After washing in PBS, cells were incubated with $10 \%$ heat-inactivated goat serum for $15 \mathrm{~min}$, with monoclonal anti-BrdU antibodies (1:20; Dako, Carpinteria, CA) for $1 \mathrm{hr}$, and with fluorescein-conjugated goat anti-mouse (GAM) $\mathrm{IgG}$ for $30 \mathrm{~min}$.

Cell viability and apoptosis assays. O-2A cells were grown for $1-2 \mathrm{~d}$ on glass coverslips under the conditions listed in Results. Cells were incubated with fluorescein diacetate (Sigma; $10 \mu \mathrm{g} / \mathrm{ml}$ ) and propidium iodide (Sigma; $20 \mu \mathrm{g} / \mathrm{ml}$ ) for $5 \mathrm{~min}$. Cells contained in five to eight $40 \times$ objective fields were counted ( $80-150$ total cells/field) per coverslip, using fluorescein and rhodamine filters on a Zeiss Axiophot (Thornwood, NY) fluorescence microscope (Jones and Senft, 1985). Viable O-2A cells appeared bright fluorescent green, whereas nonviable cells were stained in red.

Apoptotic ccll death was determined by fluorescence microscopy with the nuclear dye Hoechst 33258 (Calbiochem, La Jolla, CA). O-2A cells were incubated with GluR agonists for $22 \mathrm{hr}$ under different culture conditions and fixed in methanol/acetic acid (3:1) for $30 \mathrm{~min}$. After incubation for $15 \mathrm{~min}$ at $37^{\circ} \mathrm{C}$ with $0.4 \mu \mathrm{g} / \mathrm{ml}$ Hoechst 33258 , fluorescence was examined using a $100 \times$ Neofluar objective. Apoptotic O-2A cells were identified by nuclear condensation and/or fragmented chromatin.

Immunocytochemistry and counting of cell cultures. The following pri- 
mary antibodies were used: LB1 (Levi et al., 1986; Curtis et al., 1988), O4 (Sommer and Schachner, 1981), O1 (Sommer and Schachner, 1981), anti-nestin (Tohyama et al., 1992), and anti-GFAP (Boehringer Mannheim, Indianapolis, IN). All secondary fluorochrome-conjugated antibodies were from Cappel-Organon Teknika (Durham, NC). Double indirect immunofluorescence experiments were performed as described previously (Gallo and Bertolotto, 1990). For staining with antibodies to cell surface components (LB1, O4, and O1), live cells were incubated for 30 min with primary antibodies diluted in DMEM, followed by fluoresceinconjugated GAM IgG (for LB1) or IgM (for O4 and O1) for $20 \mathrm{~min}$. For subsequent staining with anti-nestin, cells were fixed in $4 \%$ paraformaldehyde and $0.2 \%$ glutaraldehyde (pH 7.4, in PBS) for 15 min, permeabilized in $95 \%$ ethanol $/ 5 \%$ acetic acid for $10 \mathrm{~min}$ at $-20^{\circ} \mathrm{C}$, and incubated with anti-nestin polyclonal rabbit antibody (1:1000 in $1 \% \mathrm{FBS}+0.5 \%$ bovine serum albumin) overnight at $4^{\circ} \mathrm{C}$. After incubation with goat anti-rabbit (GAR) rhodamine-conjugated $\operatorname{IgG}+\operatorname{IgM}$ for $30 \mathrm{~min}$, cells were mounted in Vectashield (Vector Laboratories, Burlingame, CA). For staining with monoclonal anti-GFAP antibody, cells were fixed and permeabilized as described above, and then incubated with anti-GFAP antibody (1:4), followed by fluorescein-conjugated GAM IgG and mounting in Vectashield. Controls for antibody specificity werc performed by sequentially omitting each of the primary antibodies in the immunostaining protocols. The immunofluorescence micrographs presented are representative of at least three experiments.

Cell migration assays. Migration of $\mathrm{O}-2 \mathrm{~A}$ cells was assayed in a two-part microchemotaxis chamber, as described in Armstrong et al. (1990b). Enriched populations of O-2A progenitor cells from neonatal rat brain were prepared as described above. To test for potential chemoattractant activity, GluR agonists (kainate, AMPA, or glutamate), a GluR antagonist (DNQX), a $\mathrm{K}^{+}$channel blocker [tetraethylammonium (TEA)], or a positive control (PDGF) (Armstrong et al., $1990 \mathrm{~b}$ ) was added to the lower well of the chemotaxis chamber. The lower wells were then covered with a poly-D-lysine-coated polycarbonate membrane with $8 \mu \mathrm{m}$ pores. The upper wells were then secured in place over the filter, and each well was filled with a suspension containing $20,000 \mathrm{O}-2 \mathrm{~A}$ progenitor cells in $54 \mu \mathrm{l}$ of defined medium (Armstrong et al., 1990b). In response to positive attractants diffusing from the lower to the upper well, the cells migrated through the pores during a $16 \mathrm{hr}$ incubation period at $37^{\circ} \mathrm{C}$. Migrated cells remained adhered to the filter on the lower surface and were labeled using Diff-Quik histological stain (American Scientific Products, McGaw Park, IL). To test for the ability to alter a chemotactic response to PDGF, the same test compounds (kainate, AMPA, glutamate, DNOX, and TEA) were each added with the cell suspension in the upper wells while PDGF $(20 \mathrm{ng} / \mathrm{ml})$ was present in the lower wells. Each condition was tested in triplicate wells for each of three separate experiments (except TEA, which was tested in a single experiment). For each well, five fields of cells were counted using a $25 \times$ objective on a Zeiss Photoscopc III.

Electrophysiology. For electrophysiological experiments, cells were either cultured with $10 \mathrm{ng} / \mathrm{ml}$ PDGF (proliferating O-2A progenitor cells) or with PDGF for $2 \mathrm{~d}$, and then in N1 $0.5 \%$ FBS for $3 \mathrm{~d}$ (prooligodendroblasts). Cells were perfused with media of the following composition (in mM): $\mathrm{NaCl} 160, \mathrm{KCl} 2.5, \mathrm{CaCl} 1.5, \mathrm{MgSO}_{4} 1.5$, glucose 10 , HEPES 10 , and $1 \mu \mathrm{M}$ tetrodotoxin. In experiments in which $\mathrm{Ca}^{2+}$ was omitted from the recording solution, $1 \mathrm{~mm} \mathrm{Co}^{2+}$ was substituted. Tight seal (>5 G $\Omega$ ) whole cell recordings (Hamill et al., 1981; Edwards et al., 1989) were made from $\mathrm{GD}^{+}{ }^{+} \mathrm{O}-2 \mathrm{~A}$ progenitors or $\mathrm{O}^{+}$oligodendroblasts. Patch electrodes had resistances of $2-6 \mathrm{M} \Omega$ when filled with (in mM): K-gluconate 130, $\mathrm{NaCl} 10, \mathrm{Na}_{2}-\mathrm{ATP} 2$, Na-GTP 0.3, HEPES 10 , EGTA 0.6, glutathione 5, buffered to $\mathrm{pH} 7.4$ and $\sim 275 \mathrm{mOsm}$. The series resistance $(6-12 \mathrm{M} \Omega$ ) was compensated to at least $85 \%$. Breakthrough into whole-cell mode was performed in current clamp; O-2A cells had a resting membrane potential of $-33.5 \pm 1.8 \mathrm{mV}(n=14)$, and prooligodendroblasts had a resting potential of $-54.3 \pm 4.4 \mathrm{mV}(n=8)$. Cells were voltage-clamped at $-70 \mathrm{mV}$ and test pulses delivered to -60 to $+45 \mathrm{mV}(+15 \mathrm{mV}$ increments, $0.1 \mathrm{~Hz}$ ). Linear leak current and the capacitive artifacts were digitally subtracted off-line using Clampfit before analysis. Records were filtered at $2 \mathrm{kHz}$ and digitized at $5 \mathrm{kHz}$.

\section{RESULTS}

\section{GluR agonists inhibit $\mathbf{O}-2 \mathrm{~A}$ cell proliferation}

A majority of freshly purified rat cortical oligodendrocyte lineage cells expressed the $\mathrm{O}-2 \mathrm{~A}$ phenotype, as determined by double
Table 1. Glutamate receptor activation inhibits $\mathrm{O}-2 \mathrm{~A}$ cell proliferation

\begin{tabular}{lcccl}
\multicolumn{5}{c}{ BrdU $^{+}$cells $(\%$ of total \pm SEM) } \\
& N1 & PDGF & bFGF & PDGF + bFGF \\
\hline Control & $21 \pm 1$ & $62 \pm 3$ & $72 \pm 1$ & $62 \pm 3$ \\
Kainate & $4 \pm 1^{*}$ & $5 \pm 2^{*}$ & $7 \pm 1^{*}$ & $10 \pm 1^{*}$ \\
AMPA & $10 \pm 2^{*}$ & $12 \pm 2^{*}$ & $27 \pm 3^{*}$ & $20 \pm 1^{*}$ \\
DNQX & $36 \pm 3^{*}$ & $77 \pm 3^{*}$ & $83 \pm 2^{* *}$ & $80 \pm 3^{* *}$ \\
\hline
\end{tabular}

O-2A progenitor cells were purified and cultured on coverslips as previously described at a density of $3 \times 10^{4}$ cells $/ \mathrm{cm}^{2}$ in DME-N1 biotin-containing medium with $0.5 \%$ FBS (Gallo and Armstrong, 1995). After $2 \mathrm{hr}$, PDGF and/or bFGF (both $10 \mathrm{ng} / \mathrm{ml}$ ), kainic acid $(200 \mu \mathrm{M})$, AMPA $(200 \mu \mathrm{M})$, or DNOX $(30 \mu \mathrm{M})$ was added to the culture medium with $25 \mu \mathrm{M}$ BrdU. After $20 \mathrm{hr}$, cells were stained with anti-BrdU antibodies as previously described (Gallo and Armstrong, 1995). A total of three coverslips (10 fields/coverslip) were counted ( $40 \times$ objective, Zeiss Axiophot) from three independent experiments for each culture condition. The total number of cells counted ranged from 407 to 653 cells for each culture condition. Under all culture conditions, AMPA and kainate significantly decreased while DNQX increased BrdU index in O-2A cells $\left({ }^{*} p<0.001 ;{ }^{* *} p<0.05\right.$ vs respective control Student's $t$ test).

immunostaining $2 \mathrm{hr}$ after seeding. The newly plated fractions were comprised of $78.1 \pm 3.8 \%(n=2624)$ of $\mathrm{GD} 3{ }^{+} /$nestin $^{+}$and $4.1 \pm 0.3 \%(n=4052)$ of ${ }^{\prime} /$ nestin cells (averages \pm SEM, 3 experiments, 20 microscopic fields/experiment were counted). A majority of remaining cells were nestin ${ }^{+} / \mathrm{GD3}^{-}$(see also Gallo and Armstrong, 1995), and only $<2 \%$ were $\mathrm{O}^{+}$or $\mathrm{GFAP}^{+}$.

PDGF, bFGF, and conditioned medium from B104 neuroblastoma cells (B104-CM) are mitogens known to stimulate O-2A proliferation (Raff et al., 1988; Bogler et al., 1990; Hunter and Bottenstein, 1990; McKinnon et al., 1990; Louis et al., 1992; Gard and Pfeiffer, 1993; Gallo and Armstrong, 1995). Rat cerebral cortex $\mathrm{O}-2 \mathrm{~A}$ cclls cultured with these mitogens for $24 \mathrm{hr}$ displayed a three- to fourfold increase in $\left[{ }^{3} \mathrm{H}\right]$ thymidine incorporation compared with cells cultured without mitogens in N1 medium (Fig. 1). Under all culture conditions, micromolar concentrations of GluR agonists (glutamate, kainate, and AMPA) significantly inhibited $\left[{ }^{3} \mathrm{H}\right]$ thymidine incorporation into $\mathrm{O}-2 \mathrm{~A}$ cells (Fig. $1 A-D$ ). As distinguished by the selective agonist AMPA, this inhibition was mediated by the AMPA GluR subtype. Similar results were also obtained in O-2A cells cultured with $30 \%$ conditioned medium from the B104 neuroblastoma cell line (B104-CM) or in O-2A cells cultured with growth factors for $24 \mathrm{hr}$, and then with GluR agonists and $\left[{ }^{3} \mathrm{H}\right]$ thymidine for the next $24 \mathrm{hr}$. The finding that GluR agonists inhibited, and DNQX stimulated, O-2A cell proliferation even in cells cultured without growth factors for $24 \mathrm{hr}$ (N1) is likely to be attributable to a significant percentage of cells undergoing a final round of division under these culture conditions (see also Table 1). The $\mathrm{IC}_{50}$ values for each agonist were measured from dose-response curves obtained in cells cultured with each GluR agonists and PDGF $(10 \mathrm{ng} / \mathrm{ml})$ or PDGF + bFGF $(10 \mathrm{ng} / \mathrm{ml}$ each; 2 experiments in triplicate for each condition; $n=$ 6 for each agonist concentration). In cells cultured in PDGF, $\mathrm{IC}_{50}$ values for kainate and AMPA were $32.8 \pm 8.4$ and $28.1 \pm 3.4 \mu \mathrm{M}$, respectively. In cells cultured in $\mathrm{PDGF}+\mathrm{bFGF}, \mathrm{IC}_{50}$ values for kainate and AMPA were $23.3 \pm 2.8$ and $10.3 \pm 2.3 \mu \mathrm{M}$, respectively. The non-NMDA antagonist DNQX $(30 \mu \mathrm{M})$ not only prevented the antiproliferative effects of kainate, but significantly stimulated $\mathrm{O}-2 \mathrm{~A}$ cell proliferation under all culture conditions tested (Fig. 1). The stimulatory effect was very likely attributable to a blockage by DNQX of the inhibitory effects of endogenous glutamate present in the culture medium, which ranged from 8.9 $\pm 0.1 \mu \mathrm{M}$ (in bFGF) to $10.2 \pm 0.4 \mu \mathrm{M}$ (in PDGF), as measured by HPLC. These concentrations of the amino acid are, in fact, within 


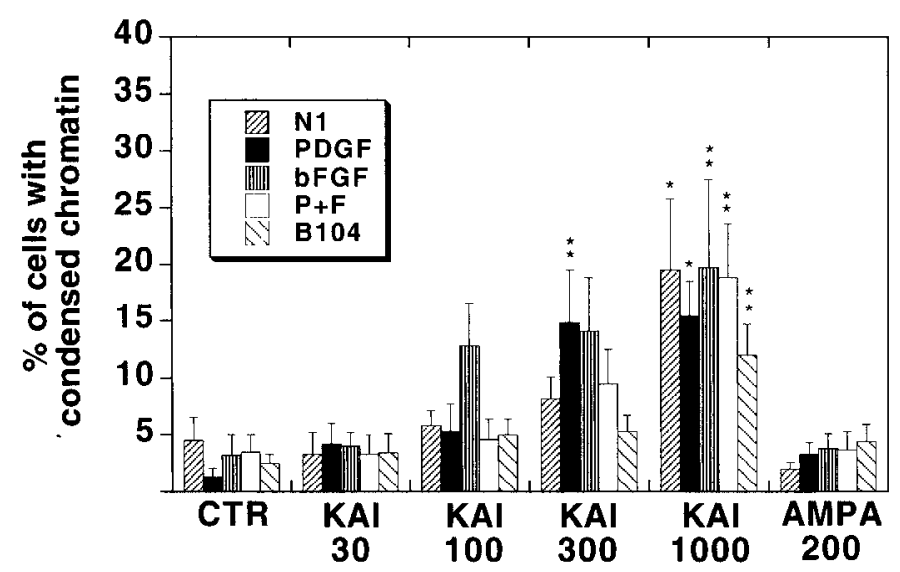

Figure 2. Glutamate receptor activation sufficient to inhibit proliferation does not cause apoptotic death of O-2A progenitor cells. Apoptotic cell death was determined by fluorescence microscopy with the nuclear dye Hoechst 33258. O-2A cells were cultured in DME-N1 $+0.5 \%$ FBS with PDGF $(10 \mathrm{ng} / \mathrm{ml})$, bFGF $(10 \mathrm{ng} / \mathrm{ml})$, PDGF । bFGF $(P \mid F)$, or $30 \%$ B104-conditioned medium (B104), as well as kainate $(K A I ; 30-1000 \mu \mathrm{M})$ or AMPA $(200 \mu \mathrm{M})$ for $22 \mathrm{hr}$. Cells were stained with Hoechst 33258 and examined by fluorescence microscopy. Histograms represent percentages of total O-2A cells, expressed as averages \pm SEM $(n=20$ microscopic fields). The total number of cells counted for each culture condition ranged from 221 to $406 .{ }^{*} p<0.01 ;{ }^{* *} p<0.05$ compared with their respective controls (Student's $t$ test). CTR, Control.

the range of activation of AMPA receptors in different types of neural cells (Wyllie et al., 1991; Patneau et al., 1992, 1994).

The antiproliferative effects of GluR agonists were also analyzed at the single-cell level by pulse-labeling O-2A cells with $\mathrm{BrdU}$ for $20 \mathrm{hr}$ to maximize the number of cells labeled during S-phase. The results summarized in Table 1 are in agreement with the $\left[{ }^{3} \mathrm{H}\right]$ thymidine incorporation assay findings. Under all culture conditions, both kainate and AMPA strongly decreased, whereas DNQX significantly increased, the percent of $\mathrm{BrdU}^{+}$cells. Similar to the results shown in Figure 1, in these experiments kainate was more efficacious than AMPA.

To demonstrate that GluR agonists did not induce neurotoxicity, O-2A cell viability was evaluated with fluorescein diacetate (FDA) and propidium iodide (PI). Under all conditions tested (same as in Fig. 1 and Table 1), $\sim 90 \%$ of $\mathrm{O}-2 \mathrm{~A}$ cells were viable $\left(\mathrm{FDA}^{+} / \mathrm{PI}^{-}\right)$after a $24 \mathrm{hr}$ exposure to GluR agonists $(20-300 \mu \mathrm{M}$; data not shown). Staining with Hoechst 33258 dye demonstrated that only concentrations of kainate above $300 \mu \mathrm{M}$ induced apoptosis in a small percentage of $\mathrm{O}-2 \mathrm{~A}$ cells (Fig. 2). These results are in agreement with previous studies (Oka et al., 1993; Yoshioka et al., 1995), which showed that millimolar concentrations of glutamate and GluR agonists are necessary to induce neurotoxic damage in cells of the oligodendrocyte lineage.

Molecular and functional studies have demonstrated previously that $\mathrm{O}-2 \mathrm{~A}$ cells also express GABA and muscarinic acetylcholine receptors (von Blankenfeld et al., 1991; Cohen and Almazan, 1994). To determine whether the effects of GluR agonists on O-2A cell proliferation were selective, we tested the effects of long-term incubation of $\mathrm{O}-2 \mathrm{~A}$ cells with agonists selective for GABA and muscarinic receptors. Neither GABA, nor muscimol or carbachol modified $\left[{ }^{3} \mathrm{H}\right]$ thymidine incorporation in $\mathrm{O}-2 \mathrm{~A}$ cells (Fig. 3). Moreover, carbachol (Fig. 3A) or GABA (data not shown) did not alter AMPA-induced inhibition of $\mathrm{O}-2 \mathrm{~A}$ cell proliferation.
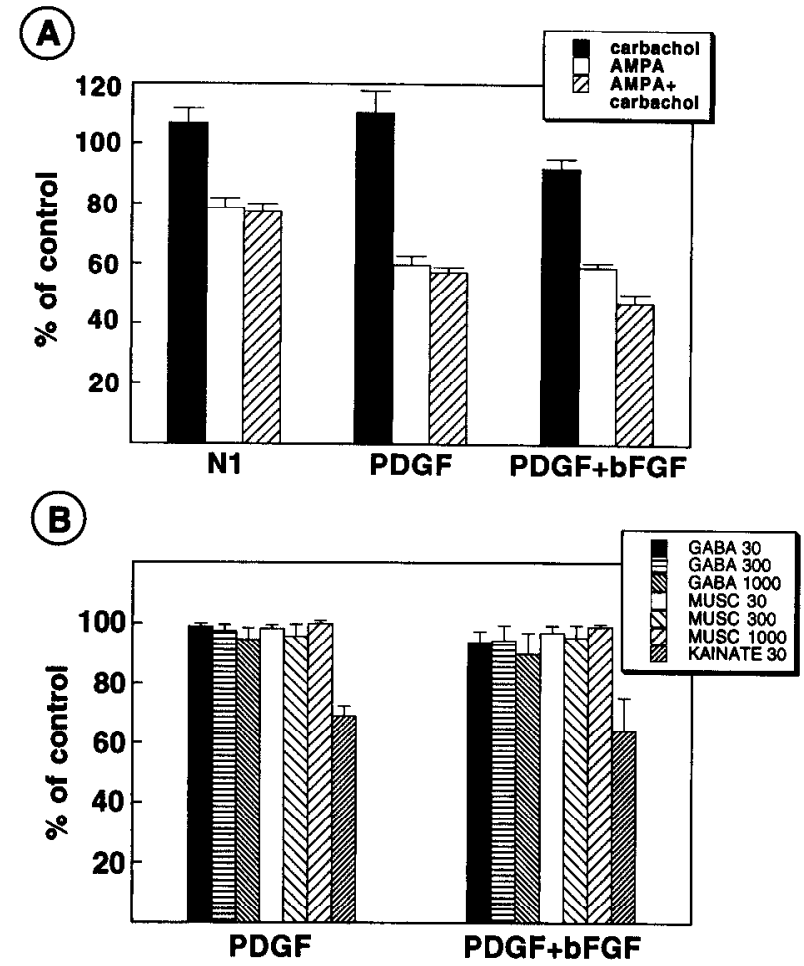

Figure 3. GABA and muscarinic receptor activation does not affect $\mathrm{O}-2 \mathrm{~A}$ cell proliferation: $\left[{ }^{3} \mathrm{H}\right]$ thymidine incorporation assays. $A$, Carbachol does not alter O-2A cell proliferation. $B$, GABA and muscimol (MUSC) do not alter $\mathrm{O}-2 \mathrm{~A}$ cell proliferation. $\mathrm{O}-2 \mathrm{~A}$ progenitor cells were cultured in DME-N $1+0.5 \%$ FBS with PDGF or PDGF + bFGF (both $10 \mathrm{ng} / \mathrm{ml}$ ). Cells were plated in 24-well plates at a density of 30,000 cells/well. After $2 \mathrm{hr}$, GABA $(30-1000 \mu \mathrm{M})$, muscimol $(30-1000 \mu \mathrm{M})$, carbachol $(100 \mu \mathrm{M})$, kainate $(30 \mu \mathrm{M})$, AMPA $(200 \mu \mathrm{M})$, or AMPA + carbachol was added to the cultures along with $\left[{ }^{3} \mathrm{H}\right]$ thymidine $(0.5 \mu \mathrm{Ci} / \mathrm{ml})$. After $22 \mathrm{hr},\left[{ }^{3} \mathrm{H}\right]$ thymidine incorporation was measured by trichloroacetic acid precipitation and scintillation counting. Averages of three experiments in triplicate \pm SEM are shown. No significant difference was detected between controls and any of the GABA and muscarinic receptor agonists.

A time course of the antiproliferative effects of GluR agonists showed that $\sim 12 \mathrm{hr}$ of incubation are required to detect a significant inhibition on $\left[{ }^{3} \mathrm{H}\right]$ thymidine incorporation in $\mathrm{O}-2 \mathrm{~A}$ cells cultured with PDGF + bFGF (Fig. 4A). Also, O-2A cells cultured with PDGF and GluR agonists for $24 \mathrm{hr}$, and then $\left[{ }^{3} \mathrm{H}\right]$ thymidinepulsed in a GluR agonist-free medium containing PDGF, reentered S-phase with a temporal pattern similar to cells that were never exposed to GluR agonists (Fig. $4 B$ ). It can be concluded, therefore, that the inhibitory effects of kainate and AMPA on $\mathrm{O}-2 \mathrm{~A}$ cell proliferation were reversible.

Activation of GluRs and subsequent opening of GluR membrane cationic channels cause a depolarization of the $\mathrm{O}-2 \mathrm{~A}$ cell membrane (Borges et al., 1994; Patneau et al., 1994). This event may trigger the release of intracellular molecules, as shown previously for newly accumulated $\left[{ }^{3} \mathrm{H}\right]$ GABA (Gallo et al., 1989, 1991). A series of experiments was performed, therefore, to exclude the possibility that the inhibitory effects of GluR agonists on $\mathrm{O}-2 \mathrm{~A}$ cell proliferation were attributable to depolarizationinduced release of an autocrine factor that in turn inhibited O-2A cell division. Cells were cultured at a density 3 - or 10 -fold lower than that routinely used, to dilute out a putative autocrine factor. Cell counts were performed after a $24 \mathrm{hr}$ incubation with GluR agonists/antagonist. Figure 5, $A$ and $B$, shows that, at both cell 
A
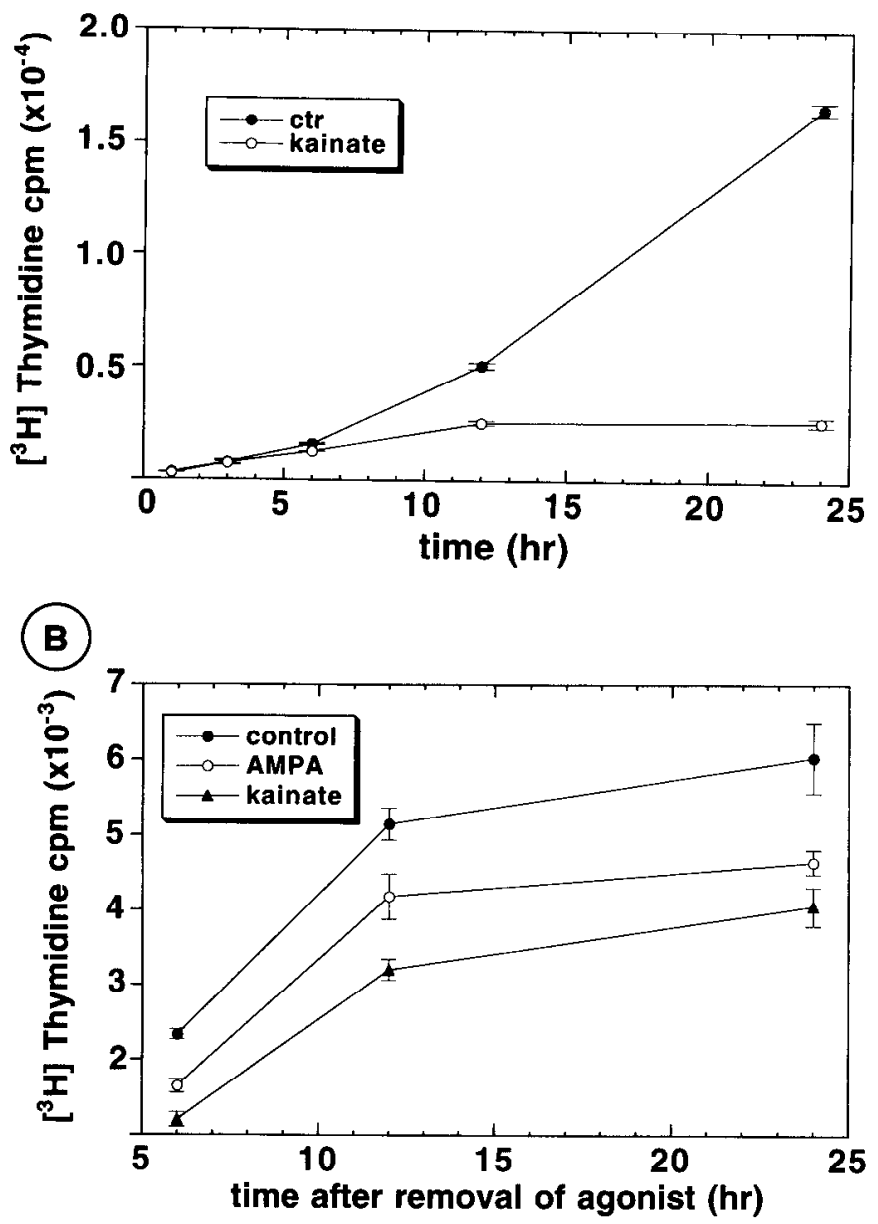

Figure 4. Time course and reversibility of the effects of glutamate receptor agonists on $\mathrm{O}-2 \mathrm{~A}$ cell proliferation: $\left[{ }^{3} \mathrm{H}\right]$ thymidine incorporation as says. $A$, Time coursc. $\mathrm{O}-2 \mathrm{~A}$ progenitor cells were plated in DME$\mathrm{N} 1+0.5 \%$ FBS in 24-well plates. After $2 \mathrm{hr}$, PDGF ( $10 \mathrm{ng} / \mathrm{ml})$, kainic acid $(100 \mu \mathrm{M})$, and $\left[{ }^{3} \mathrm{H}\right]$ thymidine $(0.5 \mu \mathrm{Ci} / \mathrm{ml})$ were added to the culture medium. Cells were harvested at $1,3,6,12$, and $24 \mathrm{hr}$ after plating, and $\left[{ }^{3} \mathrm{H}\right]$ thymidine incorporation was measured by trichloroacetic acid precipitation and scintillation counting. Averages of a triplicate experiment \pm SEM are shown. $c t r$, Control. $B$, Time course after removal of agonist. Progenitor cells were cultured in PDGF $(10 \mathrm{ng} / \mathrm{ml}$ ) in the absence (control condition) or in the presence of AMPA $(100 \mu \mathrm{M})$ or kainate $(100 \mu \mathrm{M})$. After $22 \mathrm{hr}$, all cells were shifted to fresh culture medium without GluR agonists, but containing PDGF $(10 \mathrm{ng} / \mathrm{ml})$ and $\left[{ }^{3} \mathrm{H}\right]$ thymidine $(0.5 \mu \mathrm{Ci} /$ $\mathrm{ml}$ ). At $22 \mathrm{hr}$, before the shift to agonist-free medium, kainate and AMPA inhibited $\left[{ }^{3} \mathrm{H}\right]$ thymidine incorporation by 60 and $43 \%$, respectively. Cells were harvested after 6,12 , and $24 \mathrm{hr}$ after shift to agonist-free medium and $\left[{ }^{3} \mathrm{H}\right]$ thymidinc incorporation was determined by trichloroacetic acid precipitation and scintillation counting. Averages $\pm \operatorname{SEM}(n=3)$ are shown.

densities, kainate and AMPA decreased, and DNQX increased, the total number of $\mathrm{O}-2 \mathrm{~A}$ cells/dish. These findings further confirmed that the antiproliferative effects observed are not indirectly mediated by GluR activation through the release of an inhibitory autocrine factor.

\section{GluR agonists prevent $0-2 A$ lineage progression}

Because $\mathrm{O}-2 \mathrm{~A}$ cells proliferate much more vigorously than cells at later stages of the oligodendrocyte lineage, inhibition of cell proliferation could also result from promoting $\mathrm{O}-2 \mathrm{~A}$ cell differ-
(A)

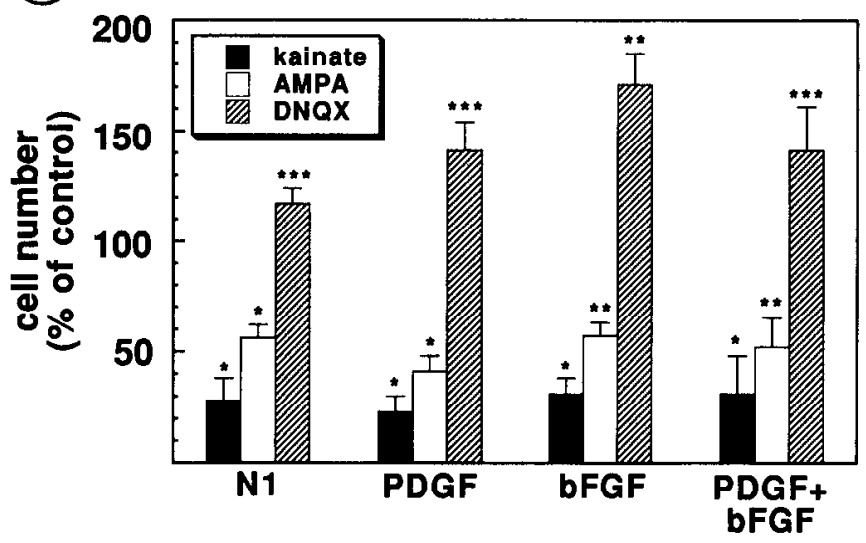

(B)

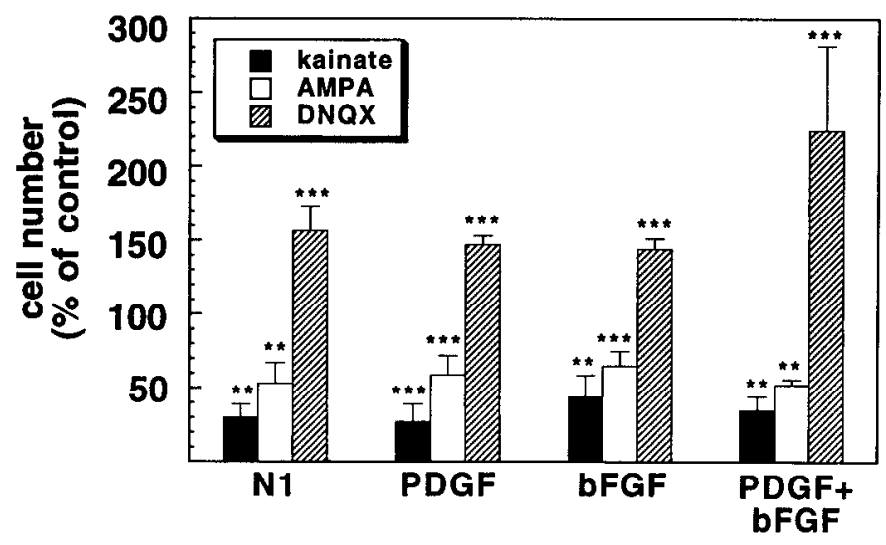

Figure 5. The inhibitory effects of glutamate receptor agonists on $\mathrm{O}-2 \mathrm{~A}$ cell proliferation are not influenced by cell density. O-2A progenitor cells were cultured in DME-N1 + 0.5\% FBS with PDGF, bFGF, ur PDGF + bFGF. Cells were plated in $35 \mathrm{~mm}$ plates at a density of $10(A)$ or $3(B)$ cells $/ \mathrm{mm}^{2}$. After $2 \mathrm{hr}, \mathrm{PDGF}$ and/or bFGF (both $10 \mathrm{ng} / \mathrm{ml}$ ), and AMPA $(200 \mu \mathrm{M})$ or DNQX $(30 \mu \mathrm{M})$ were added to the cultures. After 22 $\mathrm{hr}$, cells were fixed and counted using an inverted microscope with a $25 \times$ objective. Ten fields/plate were counted in three independent experiments. Averages \pm SEM $(n=30)$ are shown. Total number of cells counted in controls (without GluR agonists or antagonist) ranged from $5701(N 1)$ to $17,476(P D G F)$ in $A$, and from $1557(N I)$ to $3348(P D G F)$ in $B .{ }^{*} p<0.001 ;{ }^{* *} p<0.01 ;{ }^{* * *} p<0.05$ compared with their respective controls (Student's $t$ test).

entiation. Previous studies have elegantly demonstrated that the growth factors PDGF and bFGF, as well as the factors contained in B104-CM, not only promote O-2A cell proliferation, but also differentially affect lineage progression (Raff et al., 1988; Bogler et al., 1990; Hunter and Bottenstein, 1990; McKinnon et al., 1990; Louis et al., 1992; Gard and Pfeiffer, 1993; Gallo and Armstrong, 1995). We investigated the effects of GluR activation on $\mathrm{O}-2 \mathrm{~A}$ lineage progression by using antibodies to identify pre$\mathrm{O}-2 \mathrm{~A}$ cells $\left(\mathrm{GD}^{-} /\right.$nestin $\left.^{+}\right)$, O-2A cells $\left(\mathrm{GD}^{+} /\right.$nestin $\left.^{+}\right)$, prooligodendroblasts $\left(\mathrm{O}^{+}\right)$, and oligodendrocytes $\left(\mathrm{O}^{+}\right)$(Gallo and Armstrong, 1995)

Cells cultured with PDGF + bFGF for $1 \mathrm{~d}$ (Fig. $6 A, B$ ) maintained the pre-O-2A or O-2A phenotype, which was not altered after a $22 \mathrm{hr}$ exposure to kainate (Fig. $6 A, C$ ) or to AMPA (Fig. $6 A, D)$. Similar results were obtained in cells cultured with PDGF or bFGF alone for $1 \mathrm{~d}$ (data not shown). Under conditions that prevented O-2A cell differentiation for $2 \mathrm{~d}$ (i.e., PDGF $+\mathrm{bFGF}$ 

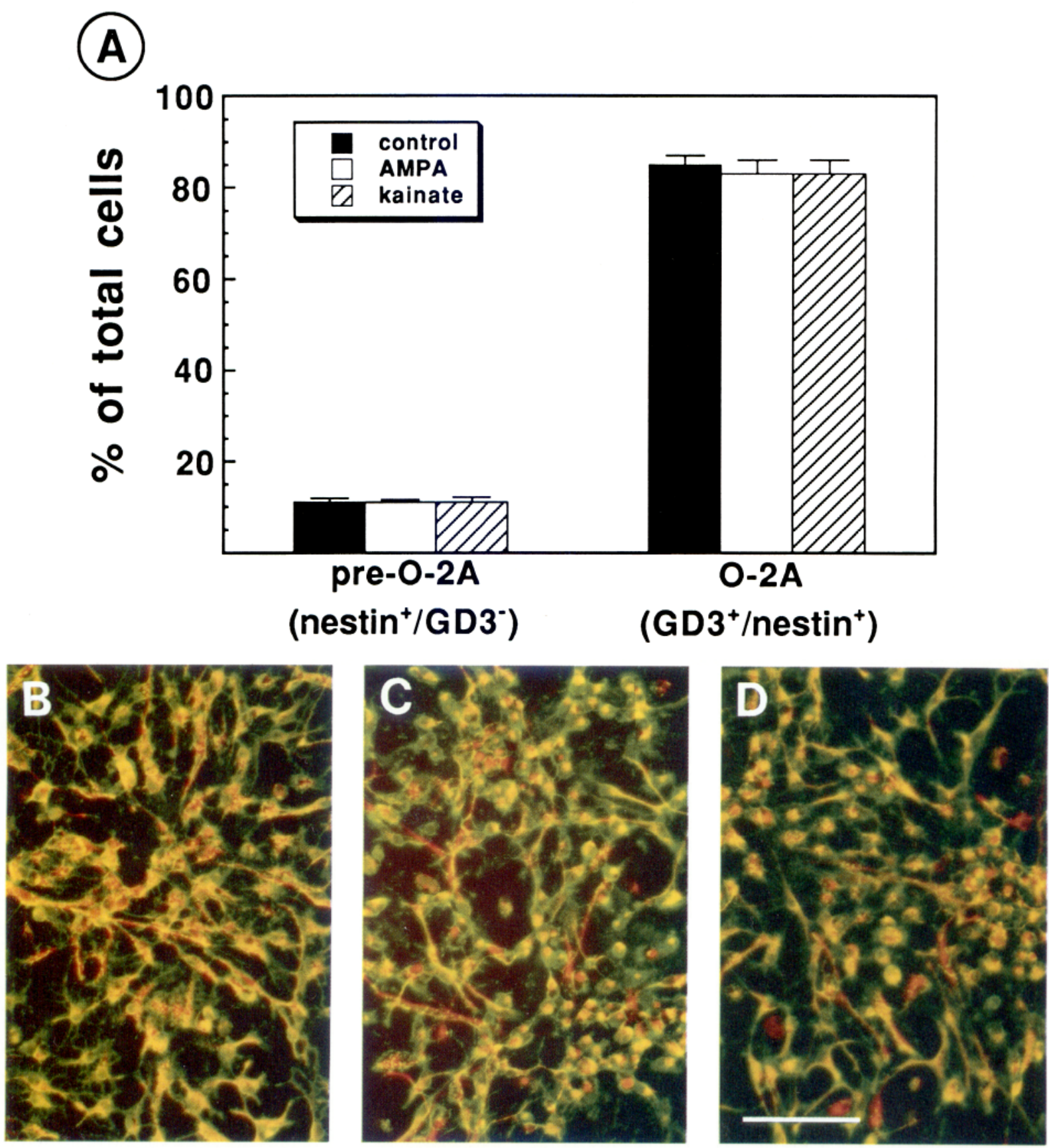

Figure 6. Activation of glutamate receptors does not affect the nestin ${ }^{+} / \mathrm{GD}^{+}$phenotype. $\mathrm{O}-2 \mathrm{~A}$ cells were cultured in DME-N1 $+0.5 \%$ FBS with PDGF + bFGF (both $10 \mathrm{ng} / \mathrm{ml}$ ), kainate $(200 \mu \mathrm{M})$, or AMPA $(200 \mu \mathrm{M})$. After $22 \mathrm{hr}$, cells were stained by double immunofluorescence with LB1 (anti-GD3; fluorescein) and anti-nestin (rhodamine) antibodies and counted. A, Quantitative analysis. A total of three coverslips (10 fields/coverslip) were counted from three independent experiments for each culture condition. The total number of cells counted ranged from 2029 to 2648 cells for each culture condition. Averages $\pm \mathrm{SEM}$ are shown $(n=30) . B-D$. Immunofluorescence microscopy. Double exposures of the same representative microscopic fields. In each condition ( $B$, control; $C$, kainate; $D$, AMPA), the O-2A cells maintained the nestin ${ }^{+} / \mathrm{GD}^{+}$phenotype. Scale bar, $100 \mu \mathrm{M}$.

or B104-CM), neither AMPA nor DNQX affected O-2A cell lineage progression (Table 2).

In contrast, under culture conditions that permitted O-2A lineage progression (i.e., N1, PDGF, or bFGF), AMPA inhibited acquisition of the $\mathrm{O} 4$ phenotype, whereas DNQX significantly increased the percentage of $\mathrm{O}^{+}$pro-oligodendroblasts (Table 2 ). Importantly, in cultures maintained in bFGF, the small percent- age of dividing $\mathrm{O}^{+}$pro-oligodendroblasts was not altered by AMPA or DNQX (Table 2).

Also, the small percentage $(<1 \%)$ of $\mathrm{O}^{+}$oligodendrocytes or $\mathrm{GFAP}^{+}$astrocytes was not altered by AMPA or DNQX (data not shown). These data indicate that long-term activation of AMPA receptors selectively prevents $\mathrm{O}-2 \mathrm{~A}$ lineage progression to the $\mathrm{O}^{+}$pro-oligodendroblast stage. 


\section{GluR agonists do not alter $\mathrm{O}-2 \mathrm{~A}$ cell migration}

$\mathrm{O}-2 \mathrm{~A}$ cells are highly motile; we therefore explored whether GluR agonists could act as chemoattractants or alter migration to PDGF, which is a known chemoattractant for O-2A cells (Armstrong et al., 1990b). In our microchemotaxis chamber assay, $\mathrm{O}$-2A cells migrated toward $\mathrm{PDGF}$-containing medium in a dosedependent manner (Fig. 7A). GluR agonists (kainate, AMPA, or glutamatc), a GluR antagonist (DNQX), and a blockcr of voltagcdependent $\mathrm{K}^{+}$channels (TEA; data not shown, see also below) did not act as chemoattractants. Importantly, O-2A progenitor migration toward PDGF was not altered when the cells were exposed to these test compounds (kainate, AMPA, glutamate, DNQX, or TEA) during the migration (Fig. $7 B$ ). The fact that migration was not altered by GluR agonists emphasizes the viability and migratory response of the $\mathrm{O}-2 \mathrm{~A}$ cells in concentrations of GluR agonists that strongly inhibit their proliferation. Finally, these findings are also consistent with previous observations demonstrating that proliferation is not required for $\mathrm{O}-2 \mathrm{~A}$ cell migration (Armstrong et al., 1990b).

\section{O-2A responses to GluR activation are mediated by delayed rectifier $\mathrm{K}^{+}$channels}

A possible mechanism by which GluR activation inhibits $O-2 A$ proliferation and lineage progression could involve membrane ionic channels, which are differentially expressed during O-2A development (Sontheimer et al., 1989; Barres et al., 1990; Borges and Kettenmann, 1995). Delayed rectifier $\mathrm{K}^{\prime}$ channels are highly expressed at the $\mathrm{O}-2 \mathrm{~A}$ stage, but downregulated in differentiated oligodendrocytes (Fig. 81,C) (see also Sontheimer et al., 1989). In O-2A cells, a slowly inactivating delayed rectifier current was activated at potentials positive to $-40 \mathrm{mV}$ ( $V_{\text {hold }}=-70 \mathrm{mV}$; Fig. $8 A$ ). Plots of the voltage dependence of activation revealed currents that were half-activated at a potential of $-15 \pm 0.5 \mathrm{mV}(n$ $=4)$. The selective $\mathrm{K}^{+}$channel blocker TEA dose-dependently blocked the delayed rectifier. At a test potential of $+45 \mathrm{mV}$, TEA $(10 \mathrm{~mm})$ attenuated the current by $75 \%$ and was reversible on return to drug-free saline (Fig. $8 A, B$ ). The block by TEA was

\begin{tabular}{|c|c|c|c|c|c|}
\hline & \multicolumn{5}{|c|}{$\mathrm{O}^{+}{ }^{+}$cells $(\%$ of total $\pm \mathrm{SEM})$} \\
\hline & N1 & PDGF & bFGF & PDGF + bFGF & B104 \\
\hline Control & $58+2$ & $32+2$ & $\begin{array}{c}48+2 \\
(12 \pm 1)\end{array}$ & $15+1$ & $16+1$ \\
\hline AMPA & $31 \pm 4^{*}$ & $11 \pm 1^{*}$ & $\begin{array}{r}21 \pm 1^{*} \\
(16 \pm 2)\end{array}$ & $12 \pm 1^{* *}$ & $20 \pm 2$ \\
\hline DNQX & $78 \pm 2^{*}$ & $47 \pm 3^{*}$ & $\begin{array}{r}72 \pm 2^{*} \\
(13 \pm 3)\end{array}$ & $19 \pm 2$ & $16 \pm 2$ \\
\hline
\end{tabular}

O-2A progenitor cells were purified and cultured on coverslips at a density of $3 \times 10^{4}$ cells $/ \mathrm{cm}^{2}$ (Gallo and Armstrong, 1995). AMPA (200 $\mu \mathrm{M}$ ) and DNOX (30 $\left.\mu \mathrm{M}\right)$ were added to the culture medium $2 \mathrm{hr}$ after plating. After $48 \mathrm{hr}$, cells were immunostained with $\mathrm{O} 4$ antibody (Gallo and Armstrong, 1995). Cells cultured in bFGF were pulsed with BrdU for 20 hi before staining with $\mathrm{O} 4$ and anti-BrdU antibudies. A substantial population of $\mathrm{O}^{+}$cells was found to proliferate only in cultures maintained with bFGF. Data in parenthesis represent the percentage of $\mathrm{O}^{+} / \mathrm{BrdU}^{++}$cells \pm SEM. Results were obtained from three independent sets of cultures $(n=30)$. $\Lambda$ total of three coverslips ( 10 fields/coverslip) were counted $(40 \times$ objective, Zeiss Axiophot) for each culture condition. The total number of cells counted ranged from 2000 to 4500 cells for each culture condition. A decrease in the percent of $4^{+}$cells was also found in cells cultured with $200 \mu \mathrm{M}$ kainate (1 experiment; not shown). Note that in cells cultured in N1, PDGF, or bFGF, $\mathrm{O}^{+}$cells were present even in the presence of AMPA. This could be attributable either to the cell cycle asynchrony or to differential sensitivity of distinct subpopulations of O-2A cells to AMPA. ${ }^{*} p<$ $0.001 ;{ }^{* *} p<0.01$ vs respective control (Student's $t$ test)

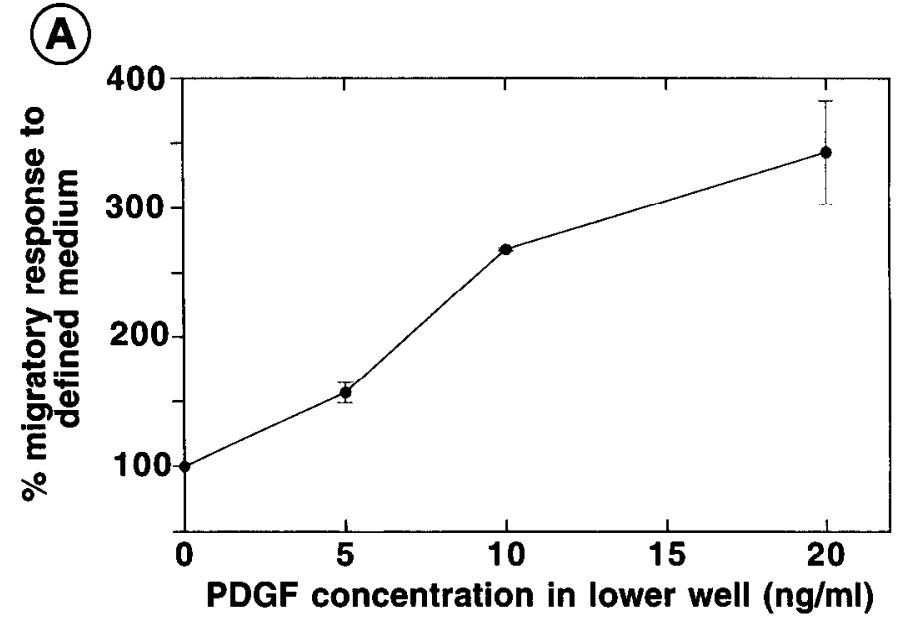

(B)

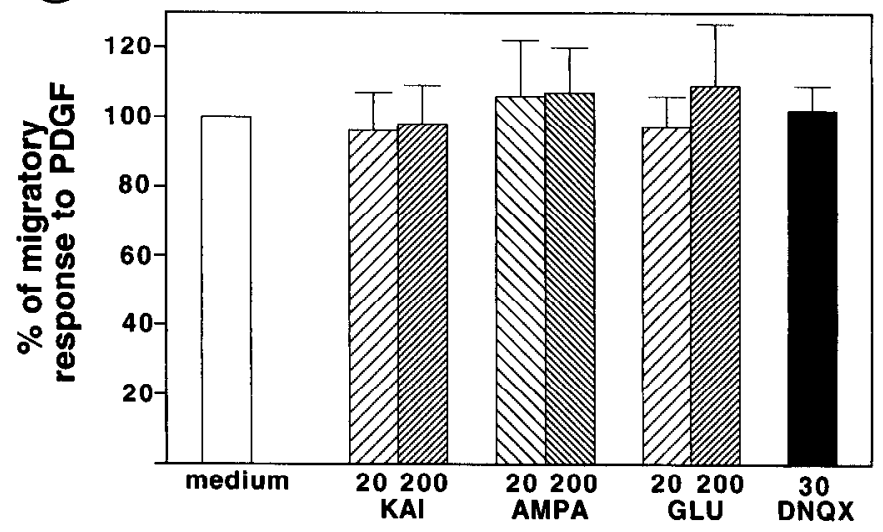

Figure 7. Glutamate receptor agonists and antagonist do not modify PDGF-induced migration of O-2A progenitor cells. Migration of purified cortical O-2A cells was assayed in microchemotaxis chambers, as described in Armstrong et al. (1990b). The chamber consists of upper and lower wells with an intervening polycarbonate membrane containing $8 \mu \mathrm{m}$ pores. $A, \mathrm{O}-2 \Lambda$ cells placed in the upper wells exhibit directed migration toward human recombinant PDGF diffusing from the lower wells during a $16 \mathrm{hr}$ migration period. The total number of migrated cells counted per well in five fields ( $25 \times$ objeclive) was $149 \pm 20$ (average \pm SEM, $n=3$ ) in defined medium. $B, \mathrm{O}-2 \mathrm{~A}$ cells placed in the upper well continue to migrate toward PDGF $(20 \mathrm{ng} / \mathrm{ml})$, diffusing from the lower well, when GluK agonists $(20$ or $200 \mu \mathrm{M})$ or DNQX $(30 \mu \mathrm{M})$ is added to the upper wells with the cells. The total number of migrated cells counted per well in five fields ( $25 \times$ objective) was $513 \pm 91$ (average $\pm \mathrm{SEM}, n=3$ ) in PDGF alone (shown as $100 \%$ ). Neither the GluR agonists nor DNQX acted as chemoattractants when placed only in the lower wells instead of PDGF (data not shown). Similar results were obtained with TEA (10 mM) added to either the upper or the lower wells (data not shown). $K A I$, Kainate; $G L U$, glutamate.

weakly dependent on the external calcium concentration $\left(\left[\mathrm{Ca}^{2+}\right\rfloor_{0}\right.$; Fig. $\left.8 B\right)$. A concentration of kainate $(200 \mu \mathrm{M})$ that inhibited $\mathrm{O}-2 \mathrm{~A}$ cell proliferation by $70 \%$, reduced the outward current at a test potential of $+45 \mathrm{mV}$ by $49 \%$ (Fig. $8 A, B$ ). The block by kainate was independent of $\left[\mathrm{Ca}^{2+}\right]_{\circ}$ (Fig. $8 B$ ) and was fully reversible on washing with drug-free saline. In all cells, addition of kainate resulted in an inward ligand-gated current ranging from 200 to $600 \mathrm{pA}$. The current-voltage relationship of the kainate response was linear and reversed polarity at $-3 \mathrm{mV}$ $(n=3)$.

In contrast, in only 5 of 10 recordings from prooligodendroblasts were we able to observe any appreciable out- 
(A)
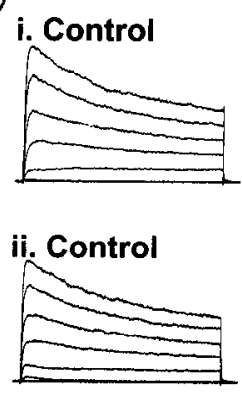

$10 \mathrm{mM}$ TEA

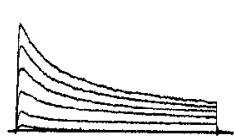

$200 \mu \mathrm{M}$ Kainate
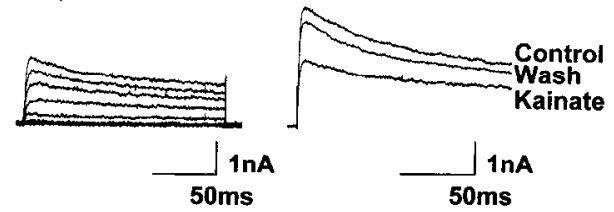

(C)

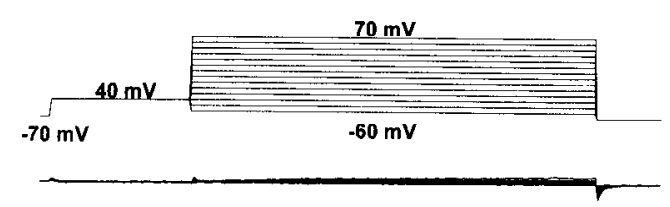

$\Lambda$
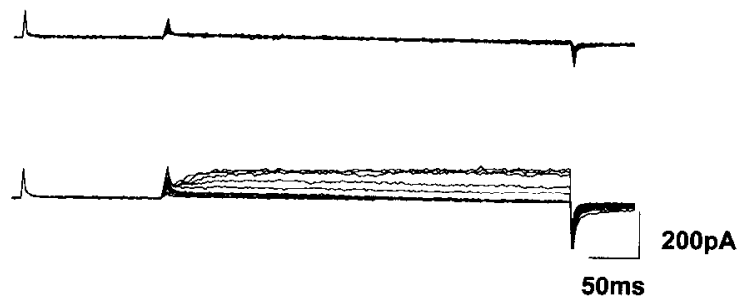

(B)

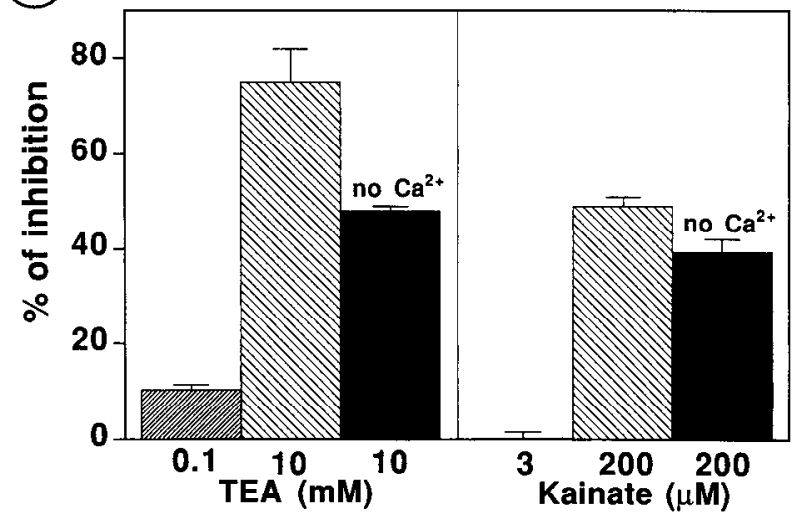

(D)

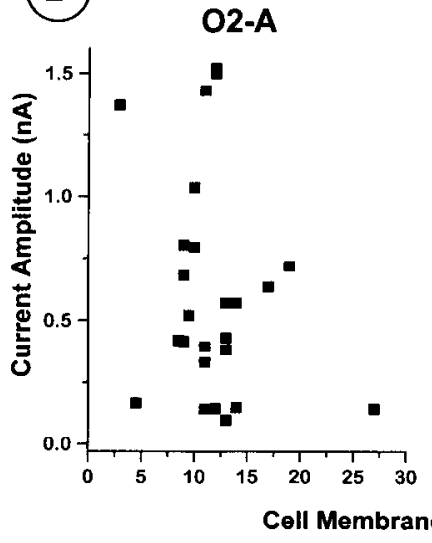

Pro-oligodendroblast

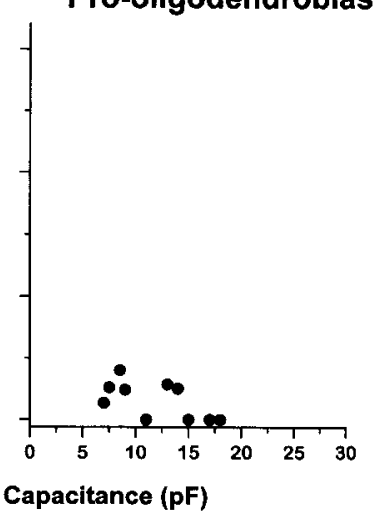

Figure 8. Glutamate receptor activation blocks delayed rectifier $\mathrm{K}^{+}$channels in O-2A cells. $A$, Patch-clamp recordings of O-2A cells demonstrate that TEA $(i)$ and kainate $(i i)$ both block delayed rectifier $\mathrm{K}^{+}$channels. $B$, TEA and kainate dose-dependently block $\mathrm{Ca}^{2+}$-independent $\mathrm{K}^{+}$conductances. Each histogram is the average \pm SEM obtained from 3-4 cells. $C$, Similar recordings made from $\mathrm{O}^{+}$pro-oligodendroblasts reveal a complete lack of outward currents (top two traces) or only small amplitude currents (bottom trace) in response to test pulses up to $+70 \mathrm{mV}\left(V_{\text {hold }}-40 \mathrm{mV}\right)$. $D$, Plots of cell membrane capacitance versus current amplitude data, obtained from recordings in either $\mathrm{O}-2 \mathrm{~A}$ cells or pro-oligodendroblasts, illustrate that despite possessing similar membrane capacitance properties, pro-oligodendroblasts do not share the wide range of current amplitudes seen in $\mathrm{O}-2 \mathrm{~A}$ cell recordings. Data points were taken from outward currents elicited at a test potential of $+70 \mathrm{mV}$.

ward current even at test potentials of up to $+70 \mathrm{mV}$. In the remaining five recordings, no appreciable outward currents were detected at any test potential (Fig. $8 C$, top two traces). In cells in which outward currents were observed, these currents were typically of small amplitude $(<250 \mathrm{pA})$ even at the most extreme test potentials (Fig. $8 C$, bottom trace). Plots of cell membrane capacitance against outward current amplitude at a test potential of $+70 \mathrm{mV}$, for both the $\mathrm{O}-2 \mathrm{~A}$ and pro-oligodendroblast data (Fig. $8 D$ ), illustrate that despite possessing a similar range of membrane capacitance, pro-oligodendroblasts do not possess currents in the amplitude range displayed by $\mathrm{O}-2 \mathrm{~A}$ cells. 'These data indicate that the outward currents observed in $\mathrm{O}-2 \mathrm{~A}$ cells are downregulated at the pro-oligodendroblast stage. The small current amplitudes observed in pro-oligodendroblasts prevented the testing of kainate on these outward currents.

Proliferation of $\mathrm{O}-2 \mathrm{~A}$ cells was inhibited by millimolar concentrations of TEA that also suppressed $\mathrm{K}^{+}$currents (Fig. $9 A$ ), but not by concentrations of TEA $(100 \mu \mathrm{M})$ or kainate $(3 \mu \mathrm{M})$ that did not significantly affect $\mathrm{K}^{+}$channel activity (Fig. $8 B$ and data not shown). Sinular to AMPA and kainate, the antiproliferative effect of TEA was also reversible. O-2A cells cultured with
PDGF + bFGF and TEA for $24 \mathrm{hr}$ and then $\left[{ }^{3} \mathrm{H}\right]$ thymidinepulsed in a TEA-free medium containing PDGF + bFGF reentered S-phase with a temporal pattern similar to cells that were never exposed to the $\mathrm{K}^{+}$channel blocker (Fig. 9B). Finally, TEA also delayed lineage progression to the $\mathrm{O}^{+}$stage in cells cultured in N1, PDGF, or bFGF, but not in cells maintained in PDGF + bFGF or in B104-CM (Fig. 9C).

\section{DISCUSSION}

Glial cells express a multitude of neurotransmitter receptors the physiological role of which is unknown. Astrocytes and oligodendrocytes are not directly involved in synaptic transmission; therefore, transmitter receptors are likely to mediate distinct processes in these cells. In the present study, we have tested the hypothesis that neurotransmitter receptors, in particular GluRs, might regulate glial cell development, and we have used purified $\mathrm{O}-2 \mathrm{~A}$ progenitor cells as an experimental model system. O-2A cells can be purified and cultured to near homogeneity, and the effects of neurotransmitter receptor activation on their development can be studied without the interference of other neural cell types. O-2A cells express glutamate, GABA, and muscarinic receptors (Gallo 

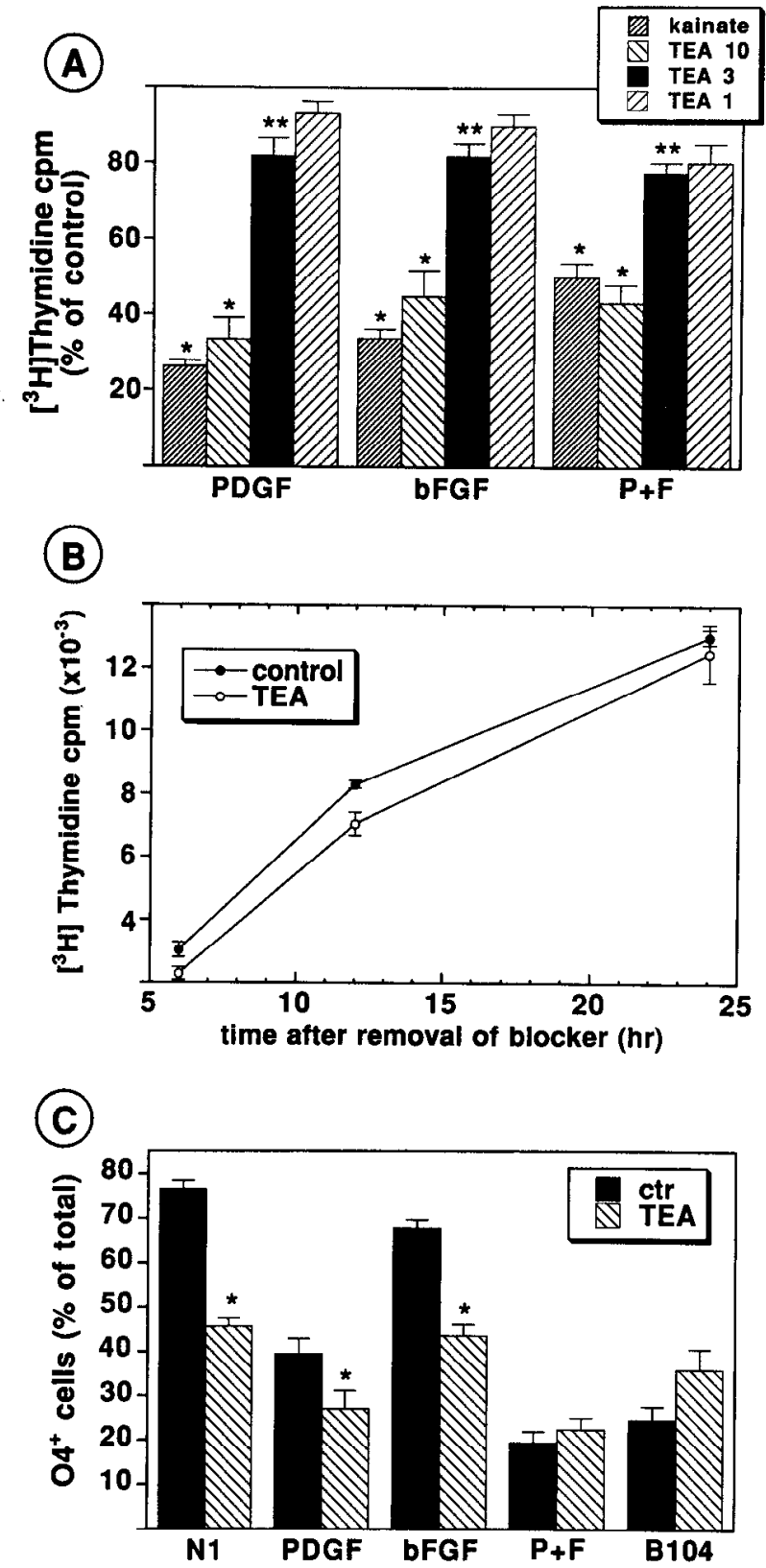

Figure 9. Blockage of delayed rectifier $\mathrm{K}^{+}$channels inhibits $\mathrm{O}-2 \mathrm{~A}$ cell proliferation and lineage progression. $A$, At concentrations that block delayed rectifier $\mathrm{K}^{+}$channels, TEA and kainate each inhibit $\mathrm{O}-2 \mathrm{~A}$ cell proliferation. Cells were plated in 24-well plates. After $2 \mathrm{hr}, \mathrm{PDGF}$ and/or bFGF (both $10 \mathrm{ng} / \mathrm{ml}$ ), as well as TEA $(1-10 \mathrm{mM})$ or kainate $(200 \mu \mathrm{M})$, were added to the cultures along with $\left[{ }^{3} \mathrm{H}\right]$ thymidine $(0.5 \mu \mathrm{Ci} / \mathrm{ml})$. After $22 \mathrm{hr},\left[{ }^{3} \mathrm{H}\right]$ thymidine incorporation was measured by trichloroacetic acid precipitation and scintillation counting. Averages \pm SEM obtained from three to six experiments run in triplicate are shown. ${ }^{*} p<0.001 ;{ }^{* *} p<$ 0.005 (Student's $t$ test). $B$, The antiproliferative effects of TEA are reversible. Progenitor cells were cultured in PDGF + bFGF (both $10 \mathrm{ng} / \mathrm{ml}$ ) in the absence or presence of TEA ( $3 \mathrm{mM})$. After $22 \mathrm{hr}$, all cells were shifted to fresh culture medium, without TEA, containing PDGF + bFGF $(P+F)$ and $\left[{ }^{3} \mathrm{H}\right]$ thymidine $(0.5 \mu \mathrm{Ci} / \mathrm{ml})$. Cells were harvested after 6,12 , and 24 $\mathrm{hr}$, and $\left[{ }^{3} \mathrm{II}\right]$ thymidine incorporation was determined by trichloroacetic acid precipitation and scintillation counting. Averages $\pm \operatorname{SEM}(n=3)$ are shown. At $22 \mathrm{hr}$, before the shift to TEA-free medium, TEA inhibited $\left[{ }^{3} \mathrm{H}\right]$ thymidine incorporation by $35 \%$. C, Blockage of delayed rectifier $\mathrm{K}^{1}$ channels with TEA prevents $\mathrm{O}-2 \mathrm{~A}$ lineage progression, as detected by staining with $\mathrm{O} 4$ antibody. $\mathrm{O}-2 \mathrm{~A}$ progenitor cells were purified and cultured on coverslips in DME-N1 medium with 0.5\% FBS with PDGF (10 $\mathrm{ng} / \mathrm{ml}), \quad$ bFGF $(10 \mathrm{ng} / \mathrm{ml}), \quad$ PDGF + bFGF, $\quad$ or $30 \%$ B104- et al., 1989; Barres et al., 1990; Wyllie et al., 1990; von Blankenfeld, 1991; Borges et al., 1994; Cohen and Almazan, 1994; Patneau et al., 1994) and can be cultured under specified conditions that promote either their proliferation or their differentiation. $\mathrm{O}-2 \mathrm{~A}$ progenitor development progresses through several stages, which can be identified by the sequential expression of developmentally regulated antigens. Distinct developmental stages in the O-2A lineage each exhibit a specific complement of membrane ionic channel types (Sontheimer et al., 1989; Barres et al., 1990; von Blankenfeld et al., 1991). Our in vitro analysis delineates the biological effects of GluR activation on O-2A development and identifies an important step in the mechanism of GluK-mediated inhibition of cell proliferation and lineage progression, which involves a distinct set of membrane ionic channcls.

The primary biological effect associated with GluR activation in cells of the oligodendrocyte lineage is inhibition of their proliferation at the O-2A developmental stage, identified by expression of the GD3 ganglioside. The pharmacological profile of the receptors involved, i.e., agonist/antagonist selectivity and efficacy, clearly points to an involvement of the AMPA receptor subtype. The range of concentration at which the GluR agonists are effective and the $\mathrm{IC}_{50}$ values derived from dose-response curves are consistent with their affinity for AMPA receptors. The finding that low micromolar concentrations of glutamate present in the culture medium tonically inhibit $\mathrm{O}-2 \mathrm{~A}$ cell proliferation, as shown by the stimulatory effects of DNQX by itself, demonstrates that the endogenous receptor ligand can exert a biological effect at physiological concentrations (see below).

Proliferating O-2A cells cultured in the presence of mitogenic factors abundantly express dclaycd rectifier $\mathrm{K}^{+}$channels, which are strongly downregulated in postmitotic $\mathrm{O}^{+}$prooligodendroblasts. These findings confirm previous results obtained by Sontheimer et al. (1989) in mouse O-2A cells cultured with horse serum, and by Barres et al. (1990) in rat optic nerve O-2A cells cultured with PDGF, showing that in the oligodendrocyte lineage the membrane channel phenotype is developmentally regulated. Expression of delayed rectifier $\mathrm{K}^{+}$channels in $\mathrm{O}-2 \mathrm{~A}$ cells is not an in vitro artifact, because oligodendrocyte precursor cells express delayed rectifier $\mathrm{K}^{+}$channels in vivo (Berger, 1995). The depolarized resting membrane potential of $\mathrm{O}-2 \mathrm{~A}$ cells suggests that the delayed rectifier will be activated at potentials close to rest and that small polarizing stimuli will strongly influence currents through these channels.

The density and activity of delayed rectifier $\mathrm{K}^{+}$channels correlate with the proliferation of cell types as diverse as $\mathrm{T}$ lymphocytes and Schwann cells, and blockage of these channcls with selective compounds strongly inhibits proliferation of both cell types (DeCoursey et al., 1984; Chiu and Wilson, 1989). Our findings demonstrate not only that blockage of delayed rectifier $\mathrm{K}^{+}$channels in O-2A cells by TEA strongly inhibits their proliferation, but also that the antiproliferative effects associated with GluR activation are mediated through blockage of the same channels. Glutamate receptor agonists and TEA suppress $\mathrm{K}^{+}$

$\leftarrow$

conditioned medium (B104). TEA ( $3 \mathrm{~mm}$ ) was added to the culture medium 2 hr after plating. After 48 hr, cells were immunostained with $\mathrm{O} 4$ antibody and counted. Averages \pm SEM obtained from two experiments $(n=20)$ are shown. The total number of cells counted for each culture condition ranged between 679 and 2184. ${ }^{*} p<0.001 ;{ }^{* *} p<0.005$ (Student's $t$ test). 
channel activity and $\mathrm{O}-2 \mathrm{~A}$ cell proliferation in the same concentration range. This indicates that blockage of these cationic channels is sufficient, possibly by a simple shift in the membrane resting potential, to cause arrest in $\mathrm{O}-2 \mathrm{~A}$ division.

The block of delayed rectifier $\mathrm{K}^{+}$channels by kainate is likely to be a consequence of the increase in $\left[\mathrm{Na}^{+}\right]_{i}$ triggered by the opening of $\mathrm{Na}^{+} / \mathrm{Ca}^{2+}$-permeable AMPA channels in the O-2A membrane. In fact, preliminary data show that replacement of $\mathrm{Na}^{+}$with $\mathrm{N}$-methyl-D-glucamine in the external solution eliminates the effects of kainate on the delayed rectifier current (P. Knutson and C. McBain, unpublished data). An increase in $\left[\mathrm{Na}^{+}\right]_{\mathrm{i}}$ has been shown to block delayed rectifier $\mathrm{K}^{+}$channels in invertebrate cells and, more recently, in mouse $\mathrm{O}-2 \mathrm{~A}$ progenitor cells (Bergman, 1970; Bezanilla and Armstrong, 1972; Borges and Kettenmann, 1995). The participation of $\mathrm{Ca}^{2+}$ ions in the GluRmediated blockage of delayed rectifier $\mathrm{K}^{+}$channels can be excluded based on the following: (1) the independence of such effect on extracellular $\mathrm{Ca}^{2+}$, and (2) the findings that carbachol (Fig. 3) and the $\mathrm{Ca}^{2+}$ ionophore $\mathrm{A} 23187$ (data not shown), which trigger $\left[\mathrm{Ca}^{2+}\right]_{\mathrm{i}}$ transients in O-2A cells (Cohen and Almazan, 1994) (V. Gallo, unpublished data), did not modify $\left[{ }^{3} \mathrm{H}\right]$ thymidine incorporation over a 24 hr tinte period.

GluR activity and suppression of delayed rectifier $\mathrm{K}^{+}$currents also block lineage progression at the $\mathrm{O}-2 \mathrm{~A}$ stage. Both activation of AMPA receptors and TEA-induced block of $\mathrm{K}^{+}$channels significantly decreased the percentage of $\mathrm{O}-2 \mathrm{~A}$ cells that progressed to the more differentiated stage identified by the monoclonal antibody O4. In the context of a "developmental clock" model (Raff et al., 1985; Temple and Raff, 1986), O-2A cells must undergo a certain number of cell divisions before progressing to the $\mathrm{O}^{+}{ }^{+}$pro-oligodendroblast stage. Therefore, GluR activation and blockage of delayed rectifier $\mathrm{K}^{+}$channels could have a unique effect on the $\mathrm{O}-2 \mathrm{~A}$ cell cycle that perturbs lineage progression as well, possibly causing an arrest in proliferation before the cell can undergo the number of divisions required to differentiate. The finding that the antagonist DNQX increased the percentage of $\mathrm{O}^{+}$cells after $48 \mathrm{hr}$ is consistent with the prediction that, when the endogenuus level of GluR-mediated block is relieved, O-2A cells can differentiate more rapidly.

Inhibition of O-2A differentiation also occurs in the presence of a different antiproliferative agent, retinoic acid (Laeng et al., 1994; Noll and Miller, 1994) (V. Gallo, unpublished observations). Interestingly, the biological effects of retinoic acid on spinal cord (Noll and Miller, 1994) or brain O-2A cells (Laeng et al., 1994) (V. Gallo, unpublished observations) are similar to those elicited by GluR agonists. In fact, retinoic acid not only inhibits $\mathrm{O}-2 \Lambda$ cell proliferation, but also prevents the transition from the $\mathrm{GD}^{+} \mathrm{O}-2 \mathrm{~A}$ to the $\mathrm{O}^{+}$pro-oligodendroblast stage (Laeng et al., 1994; Noll and Miller, 1994) (V. Gallo, unpublished observations). It can be concluded, therefore, that inhibition of $\mathrm{O}-2 \mathrm{~A}$ cell proliferation does not necessarily promote their differentiation.

We hypothesize that the neurotransmitter glutamate may cooperate with growth factors to regulate oligodendrocyte development at critical stages in vivo. Glutamate concentrations in the cerebrospinal and extracellular fluid range from 1 to $50 \mu \mathrm{M}$. (Johnson, 1978; Lerma et al., 1986), well within the range of activation of AMPA receptors in O-2A cells. Glutamate may be released from neuronal cell bodies, from axons at nodes of Ranvier, or from astrocytes (Wheeler et al., 1966; Weinreich and Hammerschlag, 1975; Dan et al., 1994; Parpura et al., 1994). During development, oligodendrocyte precursors proliferate in
CNS germinal zones, migrate to future sites of myelination, and proliferate further at these sites. O-2A cells, but not prooligodendroblasts, are capable of extensive proliferation and migration in vivo (Warrington and Pfeiffer, 1992). At the O-2A developmental stage, glutamate may counteract the mitogenic effects of growth factors, such as PDGF, without interfering with their chemotactic action, and could also prevent premature differentiation. Accordingly, GluR agonists depolarize oligodendrocyte precursors and block $\mathrm{K}^{+}$conductances in vivo (Berger, 1995). Furthermore, long-term blockage of $\mathrm{K}^{+}$channels in E13 spinal cord microexplant with TEA entirely eliminated myelination without affecting axonal growth and conduction (Shrager and Novakovic, 1995), indicating that $\mathrm{K}^{+}$channels are necessary for oligodendrocyte development.

Neurotransmitter receptors and their associated channels may play a role in the development of different neural cell lineages, as shown by the modulatory effects of GABA, glutamate, and acetylcholine receptor agonists on neuroblast and astrocyte proliferation (Ashkenazi et al., 1989; Nicoletti et al., 1990; LoTurco et al., 1995). Our analysis of oligodendrocyte development defines a physiological role not only for GluRs in glia, but also for a subtype of $\mathrm{K}^{+}$channels. The finding that the activity of delayed rectifier $\mathrm{K}^{+}$channels is closely linked to mitosis in progenitor cells of the nervous system, as in the immune system (Lewis and Cahalan, 1988), further strengthens the concept that cell proliferation and plasticity can be controlled through the modulation of preexisting receptor and channel proteins.

Note added in proof: While this manuscript was under review, a report by Liu and Almazan (1995) also showed inhibition of O-2A progenitor cell proliferation by GluR agonists.

\section{REFERENCES}

Armstrong RC, Friedrich VL, Holmes Jr KV, Dubois-Dalcq M (1990a) In vitro analysis of the oligodendrocyte lineage in mice during demyelination and remyelination. J Cell Biol 111:1183-1195.

Armstrong RC, Harvath L, Dubois-Dalcq M (1990b) Type 1 astrocytes and oligodendrocyte-type 2 astrocyte glial progenitors migrate toward distinct molecules. J Neurosci Res 27:400-407.

Ashkenazi A, Ramachandran J, Capon DJ (1989) Acetylcholine analogue stimulates DNA synthesis in brain-derived cells via specific muscarinic receptor subtypes. Nature 340:146-150.

Barres BA, Koroshetz WJ, Swartz KJ, Chun LLY, Corey DP (1990) Ion channel expression by white matter glia: the O-2A glial progenitor cell. Neuron 4:507-524.

Behar TN, Schaffner AE, Colton CA, Somogyi R, Olah Z, Lehel C, Barker JL (1994) GABA-induced chemokinesis and NGF-induced chemotaxis of embryonic spinal cord neurons, J Neurosci 14:29-38.

Berger T (1995) AMPA-type glutamate receptors in glial precursor cells of the rat corpus callosum: ionic and pharmacological properties. Glia 14:101-114.

Bergman C (1970) Increase of sodium concentration near the inner surface of the nodal membrane. Pflügers Arch 317:287-302.

Bezanilla F, Armstrong CM (1972) Negative conductance caused by entry of sodium and cesium ions into the potassium channels of squid axons. J Gen Physiol 60:588-608.

Bogler O, Wren D, Barnett SC, Land H, Noble M (1990) Cooperation between two growth factors promotes extended self-renewal and inhibits differentiation of oligodendrocyte-type-2 astrocyte (O-2A) progenitor cells. Proc Natl Acad Sci USA 87:6368-6372.

Borges K, Kettenmann H (1995) Blockade of $\mathrm{K}^{+}$channels induced by AMPA/kainate receptor activation in mouse oligodendrocyte precursor cells is mediated by $\mathrm{Na}^{+}$entry. $\mathrm{J}$ Neurosci Res 42:579-593.

Borges K, Ohlemeyer C, Trotter J, Kettenmann H (1994) AMPA/kainate receptor activation in murine oligodendrocyte precursors leads to activation of a cation conductance, calcium influx and blockade of delayed rectifying $\mathrm{K}^{+}$channels. Neuroscience 63:135-149. 
Chiu SY, Wilson GF (1989) The role of potassium channels in Schwann cell proliferation in Wallerian degeneration of explant rabbit sciatic nerves. J Physiol (Lond) 408:199-222.

Cohen RI, Almazan G (1994) Rat oligodendrocytes express muscarinic receptors coupled to phosphoinositide hydrolysis and adenylyl cyclase. Eur J Neurosci 6:1213-1224.

Curtis R, Cohen J, Fok-Seang J, Hanley MR, Gregson NA, Reynolds R, Wilkin GP (1988) Development of macroglial cells in rat cerebellum. I. Use of antibodies to follow early in vivo development and migration of oligodendrocytes. J Neurocytol 17:43-54.

Dan Y, Song H, Poo M (1994) Evoked neuronal secretion of false transmitters. Neuron 13:909 -917 .

DeCoursey TE, Chandy KG, Gupta S, Cahalan MD (1984) Voltagegated $\mathrm{K}^{+}$channels in human T-lymphocytes: a role in mitogenesis? Nature 307:465-468.

Edwards FA, Konnerth A, Sakmann B, Takahashi T (1989) A thin slice preparation for patch clamp recordings from synaptically connected neurones of the mammalian central nervous system. Pflügers Arch 414:600-612.

Fulton BP, Burne JF, Raff MC (1992) Visualization of O-2A progenitor cells in developing and adult rat optic nerve by quisqualate-stimulated cobalt uptake. J Neurosci 12:4816-4833.

Gallo V, Armstrong RC (1995) Developmental and growth factorinduced regulation of nestin in oligodendrocyte lineage cells. J Neurosci 15:394-406.

Gallo V, Bertolotto A (1990) Extracellular matrix of cultured glial cells: selective expression of chondroitin 4-sulfate by type-2 astrocytes and their progenitors. Exp Cell Res 187:211-223.

Gallo V, Russell JT (1995) Excitatory amino acid receptors in glia: different subtypes for distinct functions? J Neurosci Res 42:1-8.

Gallo V, Sucrgiu R, Giovannini C, Levi G (1989) Expression of excitatory amino acid receptors by cerebellar cells of the type-2 astrocyte cell lineage. J Neurochem 52:1-9.

Gallo $V$, Patrizio $M$, Levi $G$ (1991) GABA release triggered by the activation of neuron-like non-NMDA receptors in cultured type-2 astrocytes is carrier-mediated. Glia 4:245-255.

Gard AL, Pfeiffer SE (1990) Two proliferative stages of the oligodendrocyte lineage $\left(\mathrm{A} 2 \mathrm{~B} 5^{+} \mathrm{O} 4\right.$ and $\mathrm{O}^{+} \mathrm{GalC}^{-}$) under different mitogenic control. Neuron 5:615-625.

Goldman JE, Hirano M, Yu RK, Seyfried TN (1984) GD3 ganglioside is a glycolipid characteristic of immature neuroectodermal cells. J Neuroimmunol 7:179-192.

Hamill OP, Marty A, Neher E, Sakmann B, Sigworth FJ (1981) Improved patch-clamp techniques for high resolution current recording from cells and cell-free patches. Pflügers Arch 391:85-100.

Holzwarth JA, Gibbons SJ, Brorson JR, Philipson LH, Miller RJ (1994) Glutamate receptor agonists stimulate diverse calcium responses in different types of cultured rat cortical glial cells. J Neurosci 14:1879-1891.

Hunter SF, Bottenstein JE (1990) Growth factor responses of enriched bipotential glial progenitors. Brain Res 54:235-248.

Jacobson M (1991) Developmental neurobiology. New York: Plenum.

Jones KH, Senft JA (1985) An improved method to determine cell viability by simultaneous staining with fluorescein diacetate-propidium indide. J Histochem Cytochem 33:77-79.

Johnson JL (1978) The excitant amino acids glutamic and aspartic acid as transmitter candidates in the vertebrate central nervous system. Prog Ncurobiol 10:155-202.

Komuro H, Rakic P (1993) Modulation of neuronal migration by NMDA receptors. Science 260:95-97.

Laeng P, Decimo D, Pettmann B, Janet T, Labourdette G (1994) Retinoic acid regulates the development of oligodendrocyte precursor cells in vitro. J Neurosci Res 39:613-633.

Lauder JF (1993) Neurotransmitters as growth regulatory signals: role of receptors and second messengers. Trends Neurosci 16:233-240.

Lerma J, Herranz AS, Herreras O, Abraira V, Martin del Rio R (1986) In vivo determination of extracellular concentration of amino acids in the rat hippocampus: a method based on brain dialysis and computerized analysis. Brain Res 384:145-155.

Levi G, Gallo V, Ciotti MT (1986) Bipotential precursors of putative fibrous astrocytes and oligodendrocytes in rat cerebellar cultures express distinct surface features and "neuron-like" GABA transport. Proc Natl Acad Sci USA 83:1504-1508.
LeVine SE, Goldman JE (1988) Spatial and temporal patterns of oligodendrocyte differentiation in rat cerebrum and cerebellum. J Comp Neurol 277:441-455.

Lcvison SW, Goldman JE (1993) Both oligodendrocytes and astrocyles develop from progenitors in the subventricular zone of postnatal rat forebrain. Neuron 10:201-212.

Lewis RS, Cahalan MD (1988) The plasticity of ion channels: parallels between the nervous and immune systems. Trends Neurosci $5: 214-218$.

Liu HN, Almazan G (1995) Glutamate induces c-fos proto-oncogene expression and inhibits proliferation in oligodendrocyte progenitors: receptor characterizations. Eur J Neurosci 7:2355-2363.

LoTurco JJ, Owens DF, Heath MJS, Davis MBE, Kriegstein AR (1995) GABA and glutamate depolarize cortical progenitor cells and inhibit DNA synthesis. Neuron 15:1287-1298.

Louis JC, Magal E, Muir D, Manthorpe M, Varon S (1992a) CG-4, a new bipotential cell line from rat brain, is capable of differentiating in vitro into either mature oligodendrocytes or type-2 astrocytes. J Neurosci Res 31:193-204.

Luskin MB, McDermott K (1994) Divergent lineages for oligodendrocytes and astrocytes originating in the neonatal forebrain subventricular zone. Glia 7:9-18.

Mayer ML, Westbrook G (1987) The physiology of excitatory amino acids in the vertebrate central nervous system. Prog Neurobiol 28:197-276.

McCarthy KD, de Vellis J (1980) Preparation of separate astroglial and oligodendroglia cell cultures from rat cerebral tissue. J Cell Biol 85:890-902

McKinnon RD, Matsui T, Dubois-Daleq M, Aaronson SA (1990) FGF modulates the PDGF-driven pathway of oligodenuirocyte development. Ncuron 5:603-614.

Nicoletti F, Magri G, Ingrao F, Bruno V, Catania MV, Dell'Albani P, Condorelli DF, Avola R (1990) Excitatory amino acids stimulate inositol phospholipid hydrolysis and reduce proliferation in cultured astrocytes. J Neurochem 54:771-777.

Noll E, Miller RH (1994) Regulation of oligodendrocyte differentiation: a role for retinoic acid in the spinal cord. Development 120:649-660.

Oka A, Belliveau MJ, Rosenberg PA, Volpe JJ (1993) Vulnerability of oligodendroglia to glutamate: pharmacology, mechanisms and prevention. J Neurosci 13:1441-1453.

Patneau DK, Mayer ML, Jane DE, Watkins JC (1992) Activation and desensitization of AMPA/kainate receptors by novel derivatives of willardine. J Neurosci 12:595-606.

Patneau DK, Wright PW, Winters C, Mayer ML, Gallo V (1994) Glial cells of the oligodendrocyte lineage express both kainate- and AMPApreferring subtypes of glutamate receptor. Neuron 12:357-371.

Parpura V, Basarsky TA, Liu F, Jeftinija K, Jeftinija S, Haydon P (1994) Glutamate-mediated astrocyte-neuron signaling. Nature 369:744-747.

Raff MC, Miller RH, Noble M (1983) A glial progenitor cell that develops in vitro into an astrocyte or an oligodendrocyte depending on culture medium. Nature 303:390-396.

Raff MC, Abney ER, Fok-Seang J (1985) Reconstitution of a developmental clock in vitro: a critical role for astrocytes in the timing of oligodendrocyte differentiation. Cell 42:61-69.

Raff MC, Lillien LE, Richardson WD, Burne FJ, Noble MD (1988) Platelet-derived growth factor from astrocytes drives the clock that times oligodendrocyte development in culture. Nature 333:562-565.

Reynolds R, Wilkin GP (1988) Development of macroglial cells in rat cerebellum. II. An in situ immunohistochemical study of oligodendroglial lineage from precursor to mature myelinating cell. Development 102:409-425.

Shrager P, Novakovic SD (1995) Control of myelination, axonal growth, and synapse formation in spinal cord explants by ion channels and electrical activity. Dev Brain Res 88:68-78.

Skoff RP (1990) Gliogenesis in rat optic nerve: astrocytes are generated in a single wave beforc oligodendrocytcs. Dcv Biol 139:149-168.

Sommer I, Schachner M (1981) Monoclonal antibodies (O1 to O4) to oligodendrocyte cell surfaces: an immunocytological study in the central nervous system. Dev Biol 83:311-327.

Sontheimer H, Trotter J, Schachner M, Kettenmann H (1989) Channel expression correlates with differentiation stage during the development of oligodendrocytes from their precursor cells in culture. Neuron 2:1135-1145. 
Temple S, Raff MC (1986) Clonal analysis of oligodendrocyte development in culture: evidence for a developmental clock that counts cell divisions. Cell 44:773-779.

Thomas SA, Matsumoto AM, Palmiter RD (1995) Noradrenaline is essential for mouse fetal development. Nature 374:643-646.

Tohyama T, Lee VMY, Rorke LB, Marvin M, McKay RDG, Trojanowski JQ (1992) Nestin expression in embryonic human neuroepithelium and in human neuroepithelial tumor cells. Lab Invest 66:303-313.

von Blankenfeld G, Trotter J, Kettenmann H (1991) Expression and developmental regulation of a $\mathrm{GABA}_{\mathrm{A}}$ receptor in cultured murine cells of the oligodendrocyte lineage. Eur $J$ Neurosci 3:310-316.

Warrington AE, Pfeiffer SE (1992) Proliferation and differentiation of $\mathrm{O}^{+}$oligodendrocytes in postnatal rat cerebellum: analysis in unfixed tissue slices using anti-glycolipid antibodies. J Neurosci Res 33:338-353.
Weinreich D, Hammerschlag R (1975) Nerve impulse-enhanced release of amino acids from non-synaptic regions of peripheral and central nerve trunks of bullfrog. Brain Res 84:137-142.

Wheeler DD, Boyarsky IL, Brooks WH (1966) The release of amino acids from nerve during stimulation. J Cell Physiol 67:141-148.

Wyllie DJA, Mathie A, Symonds CJ, Cull-Candy SG (1991) Activation of glutamate receptors and glutamate uptakc in identified macroglial cells in rat cerebellar cultures. J Physiol (Lond) 432:235-258.

Yoshioka A, Hardy M, Younkin DP, Grinspan JB, Stern JL, Pleasure D (1995) $\alpha$-Amino-3-hydroxy-5-methyl-4-isoxazolepropionate (AMPA) receptors mediate excitotoxicity in the oligodendroglial lineage. J Neurochem 64:2442-2448.

Zerlin M, Levison S, Goldman JE (1995) Early patterns of migration, morphogenesis, and intermediate filament expression of subventricular zone cells in the postnatal rat forebrain. J Neurosci 15:7238-7249. 